\title{
Reconnaissance of Water Quality at Nine Dairy Farms in North Florida, 1990-91
}

\author{
By William J. Andrews
}

U.S. GEOLOGICAL SURVEY

Water-Resources Investigations Report 92-4058

Prepared in cooperation with the

FLORIDA DEPARTMENT OF ENVIRONMENTAL REGULATION 


\section{U.S. DEPARTMENT OF THE INTERIOR MANUEL LUJAN, JR., Secretary}

U.S. GEOLOGICAL SURVEY

DALLAS L. PECK, Director

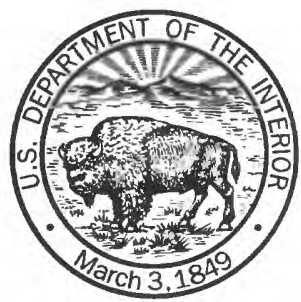

For additional information, write to:

\section{District Chief}

U.S. Geological Survey

Suite 3015

227 North Bronough Street

Tallahassee, Florida 32301
Copies of this report may be purchased from:

U.S. Geological Survey

Books and Open-File Reports Section Federal Center

Box 25425

Denver, Colorado 80225 


\section{CONTENTS}

Abstract 1

Introduction 1

Purpose and scope 2

Physical setting 2

Acknowledgments 2

Nitrogen from dairy farms 2

The nitrogen cycle 2

Waste characteristics and disposal practices 4

Hydrogeology 5

Uppermost hydrogeologic units $\mathbf{5}$

Ground-water flow 7

Methodology 7

Well installation 7

Collection and analysis of water samples 9

Data analysis $\mathbf{1 0}$

Analysis of water-quality data by water source $\mathbf{1 1}$

Wastewater lagoons $\mathbf{1 1}$

Shallow ground water $\mathbf{1 1}$

Deeper ground water 13

Analysis of ground-water quality data by hydrogeologic units

14

Surficial aquifer 14

Intermediate confining unit $\mathbf{1 4}$

Upper Floridan aquifer 15

Effects of dairy farm land uses on ground-water quality $\quad \mathbf{1 6}$

Intensive areas 16

Intensive pastures $\mathbf{1 6}$

Wastewater lagoons 16

Wastewater spray fields 17

Low-density pastures 17

Summary and conclusions 17

References 19

Appendix I-Labelled aerial photographs of the nine monitored dairy farms 21

Appendix II-Water-quality data $\mathbf{3 1}$

Figure

1. Map showing locations of dairy farms with monitoring wells 3

2. Map showing soil associations in the study area 4

3. Diagram showing the nitrogen cycle in the subsurface environment 5

4. Map showing uppermost hydrogeologic units in the study area 6

5. Diagram showing typical hydrogeologic sections in the study area $\mathbf{8}$

6. Map showing the potentiometric-surface contours and directions of ground-water flow of the Upper Floridan aquifer in the study area, May 19909

7-9. Box plots of:

7. Concentrations of dissolved nitrite plus nitrate nitrogen, ammonium nitrogen, potassium, and chloride in water from each sample source $\mathbf{1 2}$

8. Concentrations of dissolved nitrite plus nitrate nitrogen and phosphorus concentrations in water from each hydrogeologic unit $\mathbf{1 6}$

9. Concentrations of dissolved nitrite plus nitrate nitrogen, chloride, and potassium in ground water beneath various dairy farm land uses 
Table

1. Characteristics of monitored dairy farms 5

2. Monitoring-well characteristics $\mathbf{1 0}$

3. Water-quality statistics for wastewater lagoons $\mathbf{1 1}$

4. Water-quality statistics for shallow ground water 13

5. Water-quality statistics for deeper ground water 14

6. Median values for physical properties and concentrations of constituents in water from monitoring wells for the three hydrogeologic units sampled 15

7. Median values for physical properties and concentrations of constituents in water from monitoring wells classified by adjacent land use

17

Conversion Factors, Vertical Datum, and Additional Abbreviations

\begin{tabular}{lcl}
\hline \multicolumn{1}{c}{ Multiply } & \multicolumn{1}{c}{ By } & \multicolumn{1}{c}{ To obtain } \\
\hline inch (in.) & 2.54 & centimeter \\
inches per year (in/yr) & 2.54 & centimeters per year \\
foot (ft) & 0.3048 & meter \\
square foot $\left(\mathrm{ft}^{2}\right.$ ) & 0.0929 & square meter \\
acre & 0.4047 & hectare \\
acre-foot (acre-ft) & 1,233 & cubic meter \\
gallon (gal) & 0.003785 & cubic meter \\
gallon (gal) & 3.785 & liter \\
mile (mi) & 1.609 & kilometer \\
pound (lb) & 453.6 & gram \\
\hline
\end{tabular}

Temperature in degrees Fahrenheit $\left({ }^{\circ} \mathrm{F}\right)$ may be converted to degrees Celsius $\left({ }^{\circ} \mathrm{C}\right)$ as follows: ${ }^{\circ} \mathrm{C}=5 / 9 \times\left({ }^{\circ} \mathrm{F}-32\right)$.

Sea level: In this report "sea level" refers to the National Geodetic Vertical Datum of 1929 (NGVD of 1929) - a geodetic datum derived from a general adjustment of the first-order level nets of the United States and Canada, formerly called Sea Level Datum of 1929.

Additional Abbreviations

$\mathrm{mL}$ milliliter

col/ $100 \mathrm{~mL} \quad$ colonies per 100 milliliters

$\mathrm{mg} / \mathrm{L}$ milligrams per liter

MCL maximum contaminant level

$\mu \mathrm{S} / \mathrm{cm} \quad$ microsiemens per centimeter 


\title{
Reconnaissance of Water Quality at Nine Dairy Farms in North Florida, 1990-91
}

\author{
By William J. Andrews
}

Abstract

The quality of water on dairy farms in north Florida was studied by sampling water from wastewater lagoons, monitoring wells, and supply wells on nine dairy farms quarterly for 1 year for dissolved nitrate, nitrite, and ammonium nitrogen; total ammonium plus organic nitrogen, specific conductance, temperature, $\mathrm{pH}$, total phosphorus, dissolved phosphorus, dissolved potassium, dissolved sulfate, dissolved chloride, and fecal bacteria occurrence. Chemical changes in dairy cow waste as it leaches and migrates through the saturated zone were examined by comparing median values and ranges of water-quality data from dairy farm wastewater lagoons, shallow monitoring wells on dairy farms, and deeper dairy farm supply wells. The effects of hydrogeologic settings and dairy farm land uses on shallow ground-water quality were examined by stratifying the shallow ground-water-quality data set according to hydrogeologic source units and according to land uses adjacent to the monitoring wells and basic statistics of these data subsets are compared and contrasted.

Substantial differences occur between the quality of diluted dairy cow waste, shallow ground water, and deeper ground water at the nine dairy farms studied. Liquid from dairy farm wastewater lagoons, composed of dairy cow wastes diluted with supply well water, had very high median levels of the following properties and constituents: specific conductance $(2,940 \mu \mathrm{S} / \mathrm{cm})$, dissolved ammonium plus organic nitrogen (230 milligrams per liter $(\mathrm{mg} / \mathrm{L})$ ), dissolved and total phosphorus ( 25 and $44 \mathrm{mg} / \mathrm{L}$, respectively), dissolved potassium ( $200 \mathrm{mg} / \mathrm{L}$ ), dissolved chloride $(50 \mathrm{mg} / \mathrm{L})$, and median counts of fecal bacteria exceeding 100,000 colonies $/ 100 \mathrm{~mL}$. Shallow ground water from monitor wells on the nine dairy farms had lower median levels of the analyzed properties and constituents than the liquid wastewater lagoons, and higher median levels of most of the analyzed properties and constituents than deeper ground water from supply wells on the dairy farms.

Ground-water-quality data from the monitoring wells on the nine dairy farms were stratified according to their hydrogeologic source units to examine differences in water quality in the three hydrogeologic settings of the study area.
The median concentrations of nitrite plus nitrate nitrogen in ground water from a perched, sandy surficial aquifer and the Upper Floridan aquifer were enriched in dissolved nitrite plus nitrate nitrogen, relative to ground water in the intermediate confining unit $0.17 \mathrm{mg} / \mathrm{L}$ compared to 29 and $9.6 \mathrm{mg} / \mathrm{L}$ for the surficial and Upper Floridan aquifers, respectively). Ground water from the intermediate confining unit had a much higher median concentration of total and dissolved phosphorus (12 and $0.23 \mathrm{mg} / \mathrm{L}$ compared to 0.59 and $0.05 \mathrm{mg} / \mathrm{L}$, and 3.65 and $0.09 \mathrm{mg} / \mathrm{L}$ for the surficial and Upper Floridan aquifers, respectively) due in part to naturally occurring phosphatic particles in the unit.

To ascertain the relation between land uses and ground-water quality on the nine dairy farms, the groundwater-quality data set was also divided according to the following land uses: intensive areas (defoliated, high traffic areas), intensive pastures (pastures with herd densities greater than 4 head per acre), wastewater lagoons (from monitoring wells located immediately adjacent to lagoons), wastewater spray fields, and low density pastures. Shallow ground water from monitoring wells placed in or adjacent to areas with concentrated animal waste loading (wastewater lagoons, intensive areas, and intensive pastures) had high median concentrations of dissolved nitrite plus nitrate nitrogen $(11.0,26.5$, and $11.5 \mathrm{mg} / \mathrm{L})$, dissolved chloride (45.0, 35.5, and $48.5 \mathrm{mg} / \mathrm{L})$, and high median specific conductances $(614,673$, and $469 \mu \mathrm{S} / \mathrm{cm})$.

\section{INTRODUCTION}

During the past 20 years, a large number of dairy farms have commenced operation in north Florida. Currently, 81 dairy farms operate in the area with approximately 37,000 dairy cows. Where dairy cows are kept in high-density feedlots, ground water and surface water commonly contain large quantities of nitrate, ammonia, and soluble organic nitrogen species that are susceptible to nitrification to nitrate (Bashkin and Kudeyarov, 1983). Nitrate nitrogen enrichment of ground water was studied because high nitrate nitrogen concentrations in drinking water, formula, and breast milk 
may cause methemoglobinemia in infants (Vigil and others, 1965), stress the cardiovascular system with extreme artery dilation (Vrba, 1981), may increase carcinogenesis, particularly stomach cancers and leukemia (National Research Council, 1978; Strange and Krupicka, 1984; Stewart, 1990); and may cause birth defects (Scragg and others, 1982).

The Upper Floridan aquifer of the Floridan aquifer system is the principal source of potable water in the study area. Where unconfined, it is vulnerable to contamination from wastes applied to the land surface because of high recharge rates through thin, permeable surficial sands and breaches in clays overlying the aquifer. In addition to affecting the quality of ground water, wastes from dairy farms can potentially degrade the quality of nearby surface-water bodies through the runoff of nutrient-rich water that could cause eutrophication and threaten biotic communities in rivers.

The U.S. Geological Survey, in cooperation with the Florida Department of Environmental Regulation, conducted this reconnaissance study of ground-water quality at nine dairy farms in north Florida to provide the Department with more detailed information on the effects of dairy farms on ground-water quality in north Florida.

\section{Purpose and Scope}

The purpose of this study is to characterize the quality of wastewater lagoons, and ground water from monitoring and supply wells at nine dairy farms in north Florida and to examine factors affecting the quality of ground water at the dairy farms. This report presents and evaluates water-quality data obtained from I year of quarterly sampling of 34 monitoring wells drilled for the study, 6 dairy farm supply wells, 2 ephemeral ponds, and 3 wastewater lagoons located on nine dairy farms in north Florida.

Changes in constituent concentrations of waste leachate as it flows from the land surface into the saturated zone were examined by stratifying the water-quality data into three groups (wastewater lagoons, shallow ground water from monitoring wells, and deeper ground water from supply wells). The effect of hydrogeologic settings on ground-water quality at the nine dairy farms was studied by stratifying the shallow ground-water quality data from the monitoring wells, based on the source of the water in those wells: an unnamed surficial aquifer, the Upper Floridan aquifer, and an intermediate confining unit. The effects of dairy farm land uses on shallow ground-water quality at the dairy farms was examined by stratifying the water-quality data from monitoring wells on the dairy farms into five groups, based on the nearest land use to the well. These five land-use groups include: intensive areas, intensive pastures, wastewater lagoons, wastewater spray fields, and low density pastures. Basic statistics of water-quality data from these three data groupings are compared and contrasted in this report.

\section{Physical Setting}

The study area lies in the northern zone of the Florida Peninsula, which is characterized by a broad, karstic upland that extends from the northern Florida Peninsula westward to the Florida Panhandle. The nine dairy farms monitored for this study are located in Lafayette, Suwannee, Alachua, and Bradford counties (fig. 1 and app. I).

The climate in the study area is warm and temperate with air temperatures averaging $82^{\circ} \mathrm{F}$ in June, July, and August and $57^{\circ} \mathrm{F}$ in January. Rainfall averages $52 \mathrm{in} / \mathrm{yr}$ but varies widely with time and location. Average annual lake evaporation in the area is about 46 in. (Crane, 1986).

The general soil associations in the study area and a brief description of soil association characteristics are shown in figure 2. Five of the nine dairy farms (sites 4, 6, 7, 8, and 9) are underlain by well- to moderately well-drained sandy soils, with low organic matter content. These soil characteristics allow rapid infiltration of aerated water to the saturated zone. Where soils are clayey or underlain by clays, percolation rates to the saturated zone are probably lower, and surface runoff comprises a greater part of intercepted rainfall.

\section{Acknowledgments}

The author thanks Everett Kerby, Rodney Morgan, Martin Trawick, Louis Shiver, Wyatte O'Steen, Roy Johnson, Steven Reagan, the owners of the McMillan Brothers Dairy Farm, and the staff of the Institute for Food and Agricultural Sciences (IFAS) of the University of Florida for allowing access to their properties and for their interest in this study. Appreciation is also extended to Philip Coram and Mark Bardolph of the Florida Department of Environmental Regulation for their technical support for this study.

\section{NITROGEN FROM DAIRY FARMS}

Because one of the principal environmental effects of the concentrated deposition of dairy cow wastes is the elevation of nitrate nitrogen concentrations in ground water, it is useful to examine both the nitrogen cycle and typical livestock waste-management practices on dairy farms in North Florida.

\section{The Nitrogen Cycle}

Nitrate $\left(\mathrm{NO}_{3}^{-}\right)$in water is produced through a series of processes comprising the nitrogen cycle, shown schematically in figure 3. Nitrogen in wastes from dairy cows occurs in two principal forms, ammonia and organically bound nitrogen. As dairy cows deposit wastes to the land surface, some of the nitrogen in those wastes is volatilized as ammonia gas $\left(\mathrm{NH}_{3}\right)$ which is emitted to the atmosphere and returned to the land surface in low concentrations of ammonium nitrogen and nitrite plus nitrate nitrogen in rainfall. 


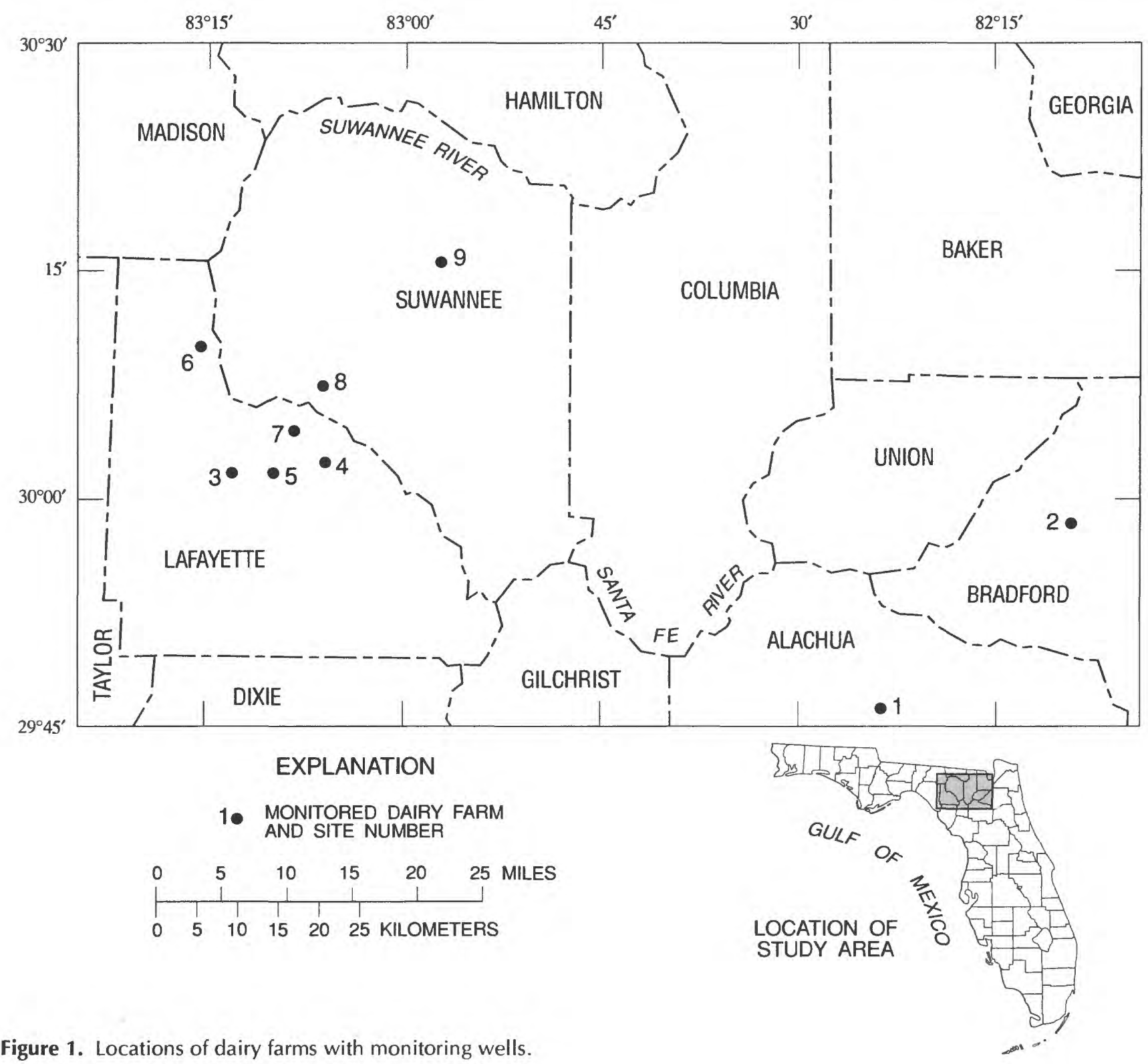

As rainwater hits the land surface, it dissolves animal wastes and other organic detritus and transports ammonium nitrogen $\left(\mathrm{NH}_{4}^{+}\right)$and organic nitrogen into soils. In soils, these forms of nitrogen are often adsorbed to clay or organic particles, where they are available for absorption by plant roots. When soils receive more nitrogen than they can adsorb and than plants on the surface can utilize, ammonium nitrogen and organic nitrogen remain in solution in soil water and can be oxidized to nitrate nitrogen through the process of nitrification that is performed by selected soil bacteria that are active in oxidized environments.

Because it is negatively charged, the nitrate molecule is not electrostatically adsorbed to negatively charged rims of soil and clay particles, as ammonium nitrogen is, so nitrate can travel downward with percolating water through the unsaturated zone to the saturated zone.

Two processes that reduce the amount of nitrate nitrogen reaching and residing in the saturated zone are plant uptake, which generally does not occur below the soil zone, and denitrification. Denitrification reduces nitrate to gaseous nitrous oxide $\left(\mathrm{N}_{2} 0\right)$ or nitrogen gas $\left(\mathrm{N}_{2}\right)$, which outgas to the unsaturated zone. Denitrification can occur either inorganically or organically in anoxic environments. Inorganic denitrification involves the transfer of oxygen atoms from nitrate to reduced metals such as iron or manganese. Organic denitrification requires an organic substrate and the presence of denitrifying bacteria which remove oxygen atoms from nitrate to respire in anoxic environments. Denitrification is especially prevalent in waterlogged, organic-rich soils, but may also occur in anoxic conditions in the saturated zone.

Nitrogen fixation, which converts nitrogen gas to proteins that can be broken down by soil bacteria to ammonium 
nitrogen and nitrite plus nitrate nitrogen, is caused by bacteria such as rhizobium which symbiotically occupy the roots of legumes and a few other types of plants. Generally, nitrogen fixation only creates ammonium nitrogen and nitrite plus nitrate nitrogen in amounts that host plants can utilize and when these nutrients are present in amounts sufficient for plant nutrition, nitrogen fixation does not occur.

\section{Waste Characteristics and Disposal Practices}

The nine dairy farms monitored in this study were selected for their typical management practices, lengths of operation, and hydrogeologic settings. Table 1 lists the following characteristics of the monitored dairy farms: years of operation, total acreage, number of cows, and waste-management

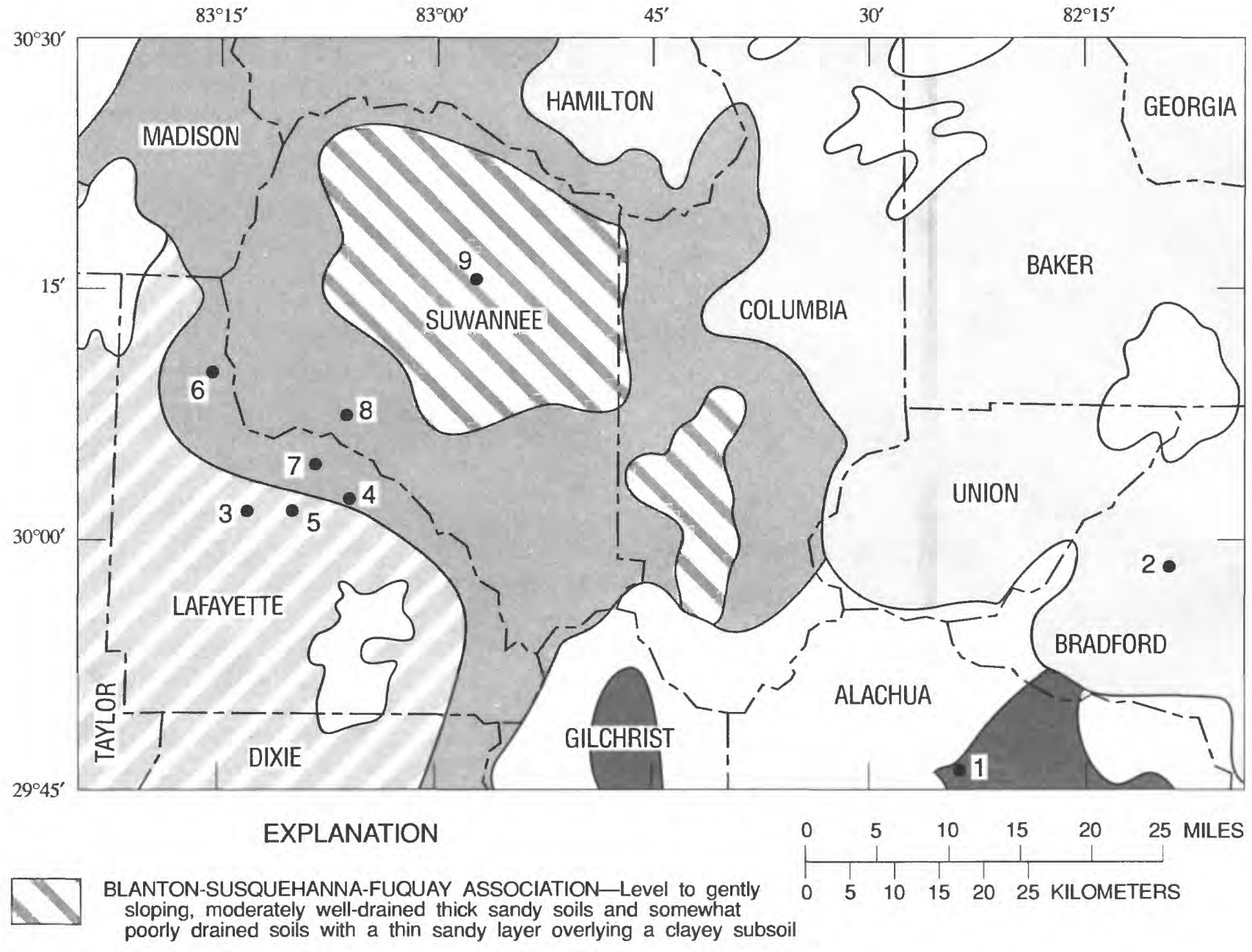
ALPIN-BLANTON-CHIPLEY ASSOCIATION-Excessively-drained thick
sandy soils with thin loamy sand bands in the subsoil and moderately
well-drained thick sandy soils

CENTENARY-LEON-PLUMMER ASSOCIATION-Nearly level poorly drained sandy soils, some with dark or loamy subsoils

LEON-PELHAM-MASCOTTE ASSOCIATION-Nearly level poorly drained soils, some with dark or loamy subsoils

POMONA-WAUCHULA-PLACID ASSOCIATION-Nearly level, poorly drained, sandy soils with a dark sandy subsoil underlain by loamy subsoil and very poorly drained thick sandy soils with a thick dark surface layer

SOIL ASSOCIATIONS NOT FOUND ON STUDY SITES

1 - MONITORED DAIRY FARM AND SITE NUMBER

Figure 2. Soil associations in the study area. (Modified from Caldwell and Johnson, 1982.) 
practices. Most dairy farms in the study area wash wastes accumulated in barns into unlined lagoons excavated in surficial sands. Wastewater from some of these lagoons is sprayed on pastures or cropland to supply grass or crop nutrient requirements in areas designated as spray fields in this report. The high concentration of potassium in cow manure and the availability of manure can limit the amount of lagoon effluent that can be applied to cropland, so additional synthetic nitrogen and phosphorus fertilizers may be applied to cropland receiving wastewater (Grundy, 1980, p. 183). Some lagoons are rarely pumped out and lose their contents through a combination of evaporation, seepage, and overflows.

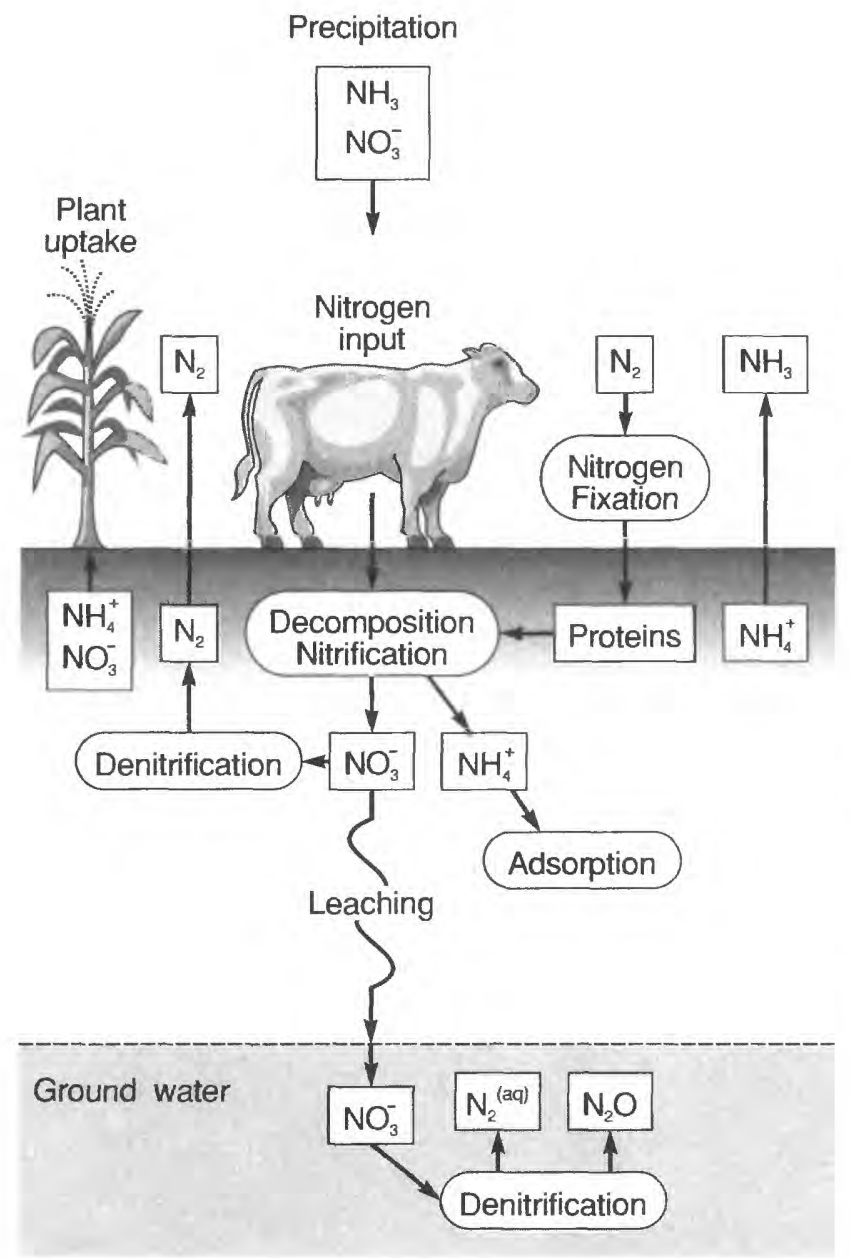

\section{DENITRIFIERS:}

Reduced metals Bacteria:

Pseudomonas

Thiobacillus

Micrococcus

denitrificans

Figure 3. The nitrogen cycle in the subsurface environment (Modified from Freeze and Cherry, (C) 1979, p. 414. Published with permission of Prentice Hall, Englewood Cliffs, N.J.)
Table 1. Characteristics of monitored dairy farms

\begin{tabular}{|c|c|c|c|c|}
\hline $\begin{array}{l}\text { Dairy } \\
\text { farm } \\
\text { site } \\
\text { number }\end{array}$ & $\begin{array}{c}\text { Years } \\
\text { of } \\
\text { opera- } \\
\text { tion }\end{array}$ & $\begin{array}{c}\text { Total } \\
\text { acreage }\end{array}$ & $\begin{array}{c}\text { Number } \\
\text { of } \\
\text { cows }\end{array}$ & Waste-management features \\
\hline 1 & 42 & 1,080 & 500 & $\begin{array}{l}\text { Two-stage lagoon, sprays } \\
\text { lagoon fluid to cropland }\end{array}$ \\
\hline 2 & 3 & 172 & 300 & Rotates herd through pastures \\
\hline 3 & 10 & 240 & 265 & $\begin{array}{l}\text { Sprays lagoon fluid on pasture } \\
\text { and cropland }\end{array}$ \\
\hline 4 & 11 & 192 & 307 & Sprays lagoon fluid on pasture \\
\hline 5 & 5 & 240 & 300 & Rotates herd through pastures \\
\hline 6 & 37 & 700 & 410 & $\begin{array}{l}\text { Sprays lagoon fluid to pasture } \\
\text { and cropland }\end{array}$ \\
\hline 7 & 10 & 80 & 175 & Rotates herd through pastures \\
\hline 8 & 9 & 470 & 550 & Sprays lagoon fluid on pastures \\
\hline 9 & 19 & 218 & 170 & Rotates herd through pastures \\
\hline
\end{tabular}

Areas on dairy farms that have been defoliated by large amounts of dairy cow traffic are referred to as intensive areas in this report. Intensive areas are generally paved with a mixture of dairy cow manure and topsoil. These manuretopsoil mixtures from intensive areas may occasionally be removed to be spread on cropland, or, more commonly, the cow traffic patterns are changed and these areas lie fallow for a period of time. Where herds are kept in pastures at densities greater than four cows per acre, referred to as intensive pastures in this report, only coarse grasses survive and manure deposits are nearly continuous. Manure is generally not removed from intensive pastures, but herds are often moved to other areas to allow these pastures to lie fallow. Low-density pastures have finer-textured grasses and are only sporadically marked with animal wastes, which are not removed.

\section{HYDROGEOLOGY}

In addition to being affected by fertilization, cropping, and waste-management practices, shallow ground-water quality on dairy farms is also affected by the compositions of the uppermost hydrogeologic units and by the nature of ground-water flow through those units. The following sections briefly describe hydrogeologic characteristics of three hydrogeologic units in the study area.

\section{Uppermost Hydrogeologic Units}

The surficial aquifer, which occurs primarily in the southwestern part of the study area (fig. 4), consists of poorly sorted, unconsolidated quartz sands and silts of Pliocene to Pleistocene age. These sands vary in thickness from less than $1 \mathrm{ft}$ in the eastern part of the study area to greater than $40 \mathrm{ft}$ 


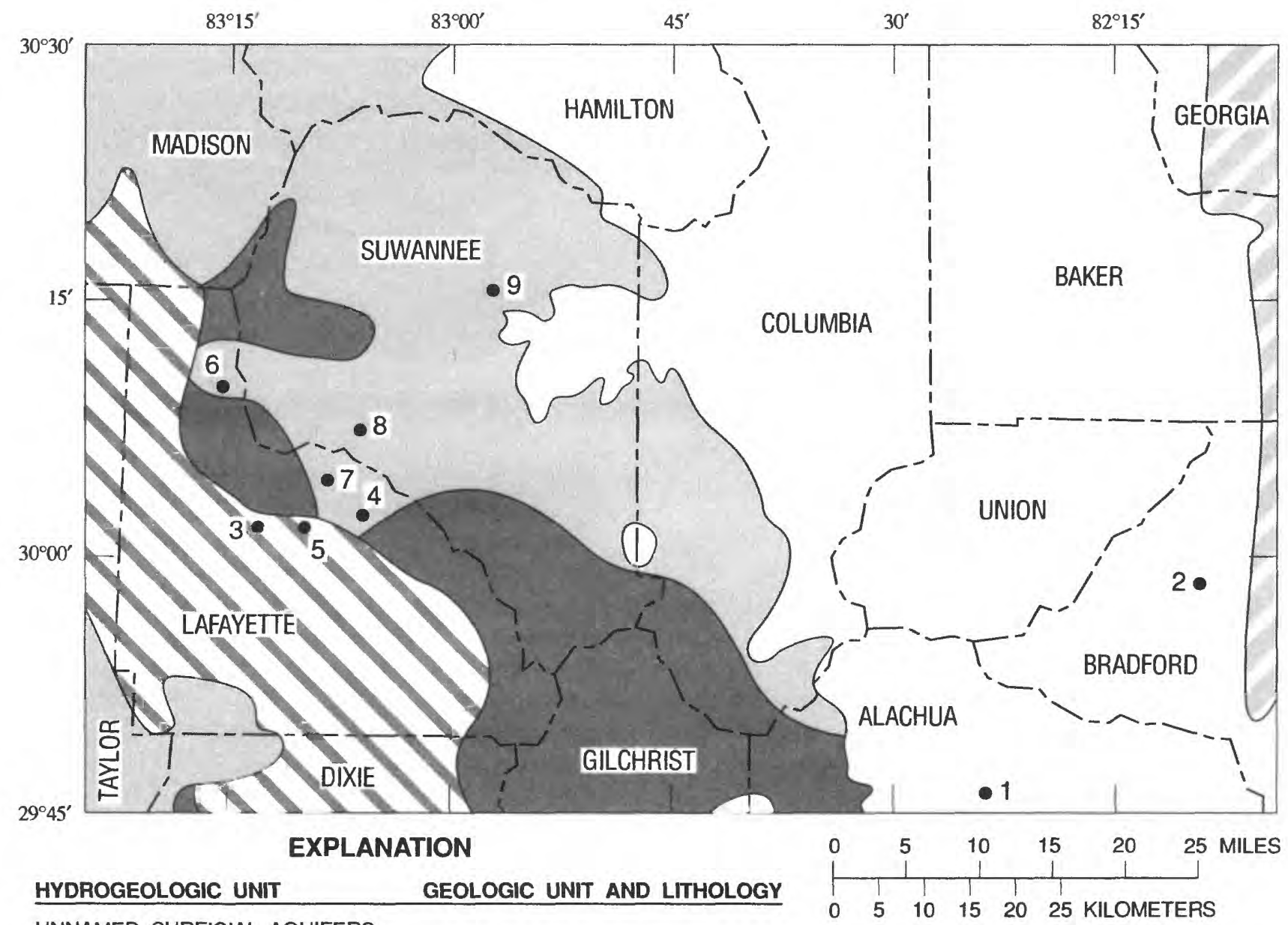

UNNAMED SURFICIAL AQUIFERS

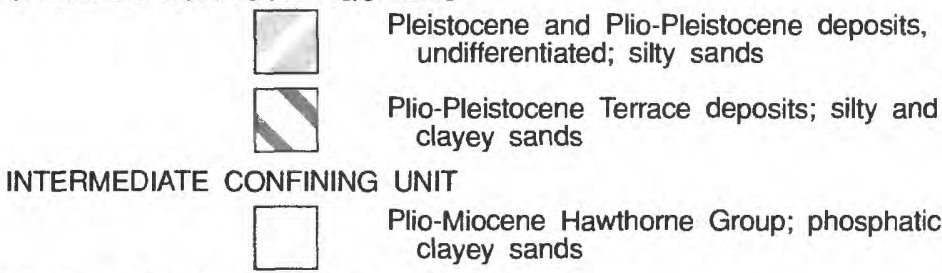

UPPER FLORIDAN AQUIFER

Oligocene Suwannee Limestone; limestone
and cherty dolomite

Eocene Ocala Limestone; limestone

\section{MONITORED DAIRY FARM AND SITE NUMBER}

Figure 4. Uppermost hydrogeologic units in the study area. (Modified from Brooks (1981), Crane (1986), and Lawton (1977).)

in the western part of the study area. The surficial aquifer is generally underlain by a sequence of thinly bedded micritic limestone and clays of the Upper Floridan aquifer. The water table in the surficial aquifer generally occurs from 4 to $15 \mathrm{ft}$ below the land surface.

In the eastern part of the study area, the uppermost hydrogeologic unit is the intermediate confining unit (composed of the Hawthorn Group ${ }^{l}$ ) which consists of heterogeneous mixtures of clay, quartz sand, dolomitic sand, and phosphate (Scott, 1983, p. 10). The intermediate confining unit is thin to nonexistent in the vicinity of the Suwannee River in north Florida, but can reach thicknesses exceeding $300 \mathrm{ft}$ in the eastern part of the study area (Scott, 1983, fig. 6; Miller, 1986, pl. 25). The water table in this unit generally occurs from 2 to $12 \mathrm{ft}$ below the land surface.

'Geologic terminology in this report conforms to usage of the Florida Geological Survey. 
The Upper Floridan aquifer in the central part of the study area consists of the Suwannee and Ocala Limestones (fig. 4), both of which commonly lie below 30 to $40 \mathrm{ft}$ of surficial sands and residual clays. The Suwannee Limestone consists of two members: an upper member consisting of shell hash, and a lower member consisting of consolidated dolomitized vuggy limestone that is often silicified (Miller, 1986, p. B32-B33). The Ocala Limestone underlies thin sand and clay deposits in the southwestern part of the study area; in other areas it underlies the Suwannee Limestone. The Ocala Limestone consists of two members: the upper member is a soft, porous coquina; the lower member is a fine-grained, soft to semi-indurated, limestone (Miller, 1986, p. B30). Where the Upper Floridan aquifer is unconfined in the study area, the water table generally occurs from 30 to 40 ft below the land surface.

\section{Ground-Water Flow}

The three principal hydrogeologic settings that occur in the study area are shown schematically in figure 5. An unconfined surficial aquifer (shown in fig. 5A) directly overlies the Upper Floridan aquifer in the southwestern part of the study area, where dairy farms 3 and 5 are located. Rainfall readily infiltrates the permeable silty sands of this aquifer and after percolating down to the water table, ground water either seeps laterally to surface streams or marshes, or seeps downward to recharge the Upper Floridan aquifer, provided that heads in the Upper Floridan are lower than those in the surficial aquifer (Miller, 1986, p. B40). The altitude of the water table in the surficial aquifer fluctuates rapidly in response to rainfall.

In the eastern part of the study area where dairy farms 1 and 2 are located (represented by fig. 5B), the uppermost hydrogeologic unit is the intermediate confining unit which consists of complexly interbedded, phosphatic, sandy clay. Due to the low permeability of these deposits, much of the rainfall falling on areas underlain by this unit runs off into ponds, wetlands, and creeks. Because heads in the confining unit are higher than those in the Upper Floridan aquifer, some ground water seeps from the confining unit down to the Upper Floridan aquifer.

The Upper Floridan aquifer is generally unconfined in the central part of the study area, where dairy farm sites 4,6 , 7,8 , and 9 are located (represented by fig. 5C). The Upper Floridan aquifer in the study area consists of highly permeable limestones that have either high intergranular or moldic porosities or high secondary porosity from karstic dissolution (Miller, 1986, p. B54-55). After water seeps to the saturated zone in the Upper Floridan aquifer, it flows laterally to discharge into rivers in the study area or toward the Gulf of Mexico. Potentiometric surface contours and flow directions for the Upper Floridan aquifer are shown in figure 6. Solution channels are common in the Upper Floridan aquifer adjacent to the Suwannee River, and springs are common along the river. Ground water flows from the aquifer to the river when the river lies at a lower elevation than the potentiometric surface of the aquifer. During periods of high precipitation and runoff, the surface elevation of the river rises above the potentiometric surface of the aquifer, the normal flow direction is reversed adjacent to the river, and riverwater flows into the aquifer (Crane, 1986, p. 72-73).

\section{METHODOLOGY}

From February to March 1990, 34 monitoring wells were installed at nine dairy farms in north Florida. Wastewater lagoons, monitoring wells, supply wells, and ephemeral ponds on these dairy farms were sampled between March 1990 and February 1991. Methods used for well installation, sample collection and analyses, and data analysis are discussed in the following sections.

\section{Well Installation}

Monitoring and supply well characteristics including: well numbers, well depths, land uses near the wells, and hydrogeologic units tapped by the wells are listed in table 2 . Two drilling methods were used to install monitoring wells on the dairy farms: hollow-stem auger, and rotary. In areas where the water table was located in unconsolidated sediments, hollow-stem augers were advanced until approximately $10 \mathrm{ft}$ of saturated thickness had been penetrated. Two-inch-diameter polyvinyl chloride (PVC) threaded casing tipped with $10 \mathrm{ft}$ of capped PVC screen was lowered into the augers, and the augers were removed from the ground. Where possible, natural material from the bottom of the drill hole was segregated from near-surface cuttings and was used to pack well screens. Pure quartz sand or washed gravel was used for packing the other well screens to approximately $3 \mathrm{ft}$ above the top of the screens. Above the screen packings, bentonite pellets were emplaced and hydrated; then neat Portland Type I cement was pumped into the borehole by tremie pipe, filling the annulus to the land surface. Steel well protectors were set into the top of the grout around most of the wells.

Where the water table occurred in the consolidated part of the Upper Floridan aquifer, boreholes were augered to the top of the consolidated rock, and the augers were removed from the boreholes. Approximately $10 \mathrm{gal}$ of neat Portland Type I cement was then tremied to the bottom of the open borehole and 4-in, diameter PVC well casing was inserted into the cement to assure sealing at the rock interface. The annular space was subsequently grouted to the surface with 
A. SANDY SURFICIAL AQUIFER

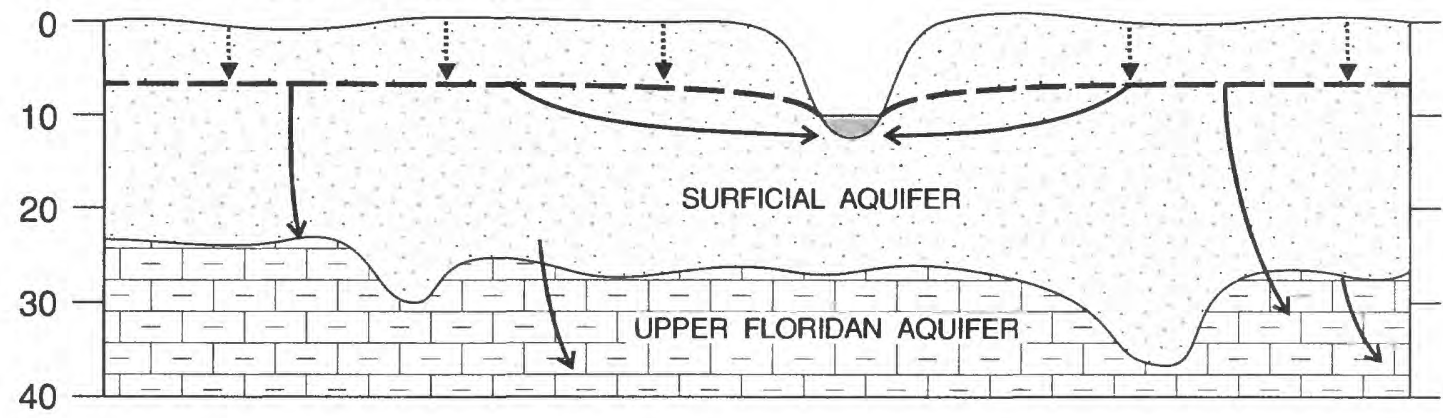

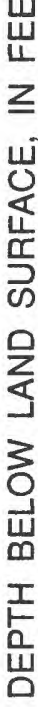

\section{B. INTERMEDIATE CONFINING UNIT}

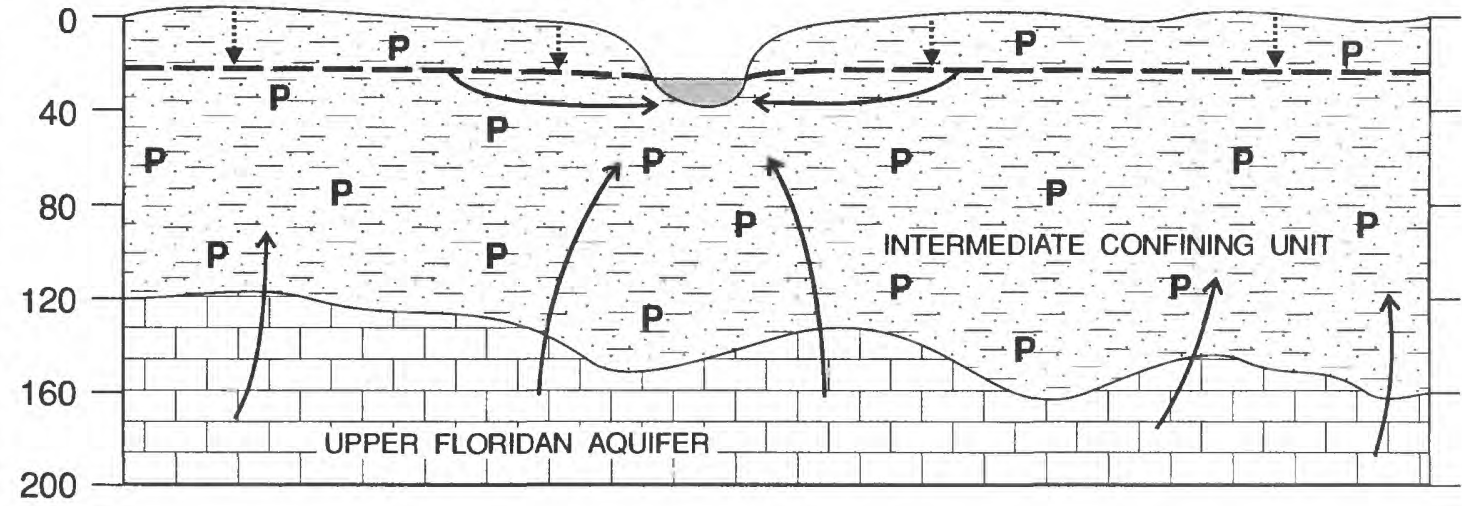

少

\section{UNCONFINED UPPER FLORIDAN AQUIFER}

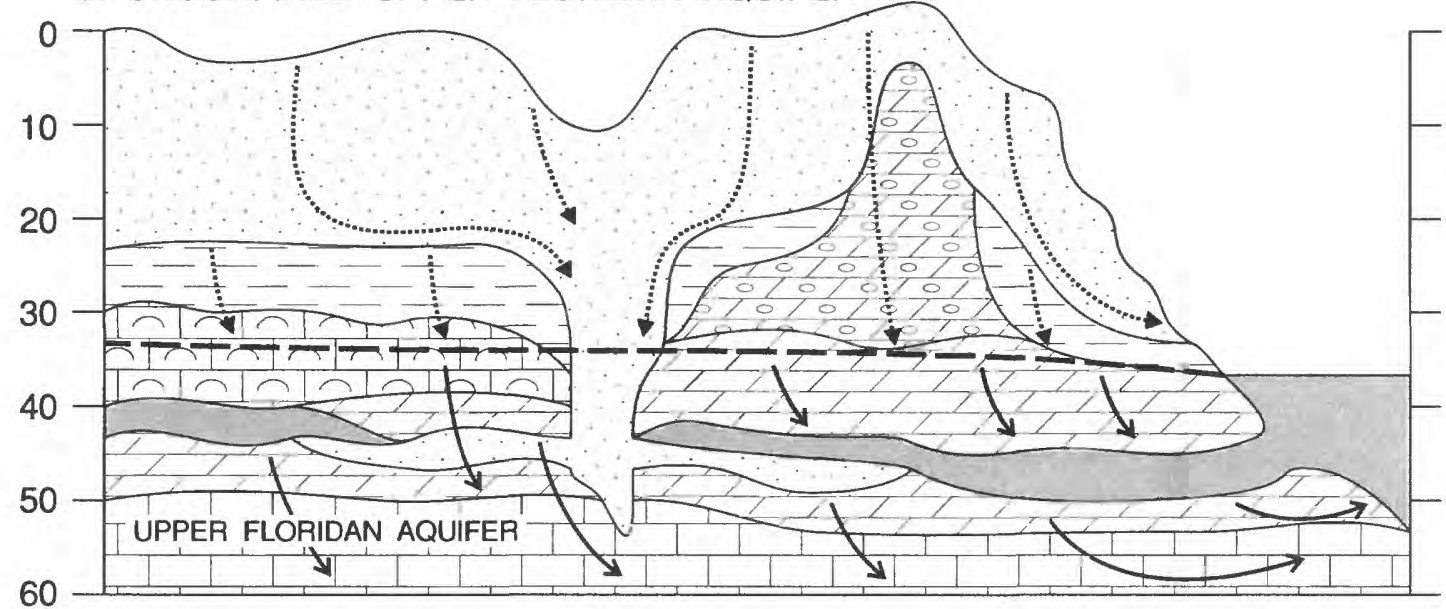

EXPLANATION
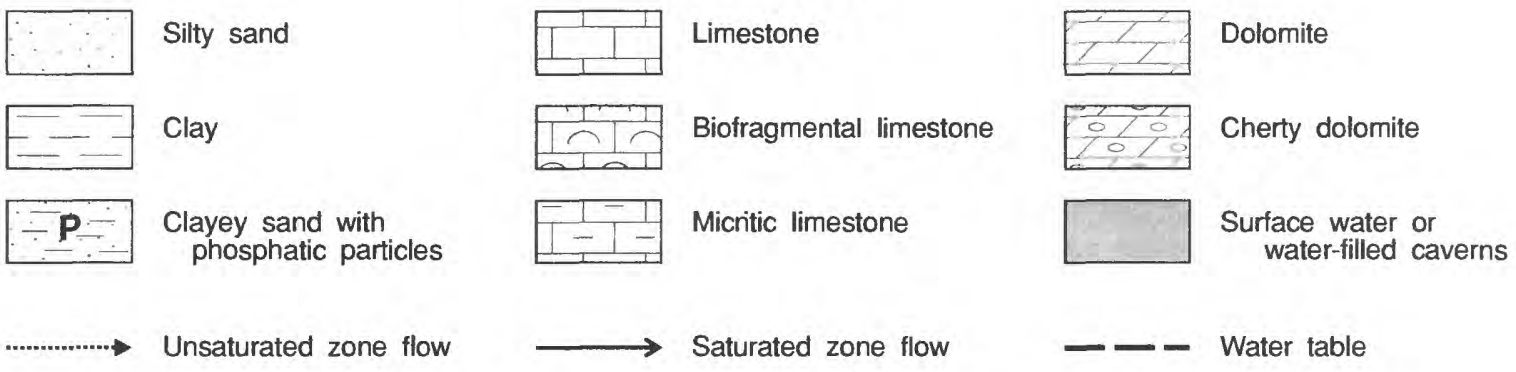

- - Water table

Figure 5. Typical hydrogeologic sections in the study area. 


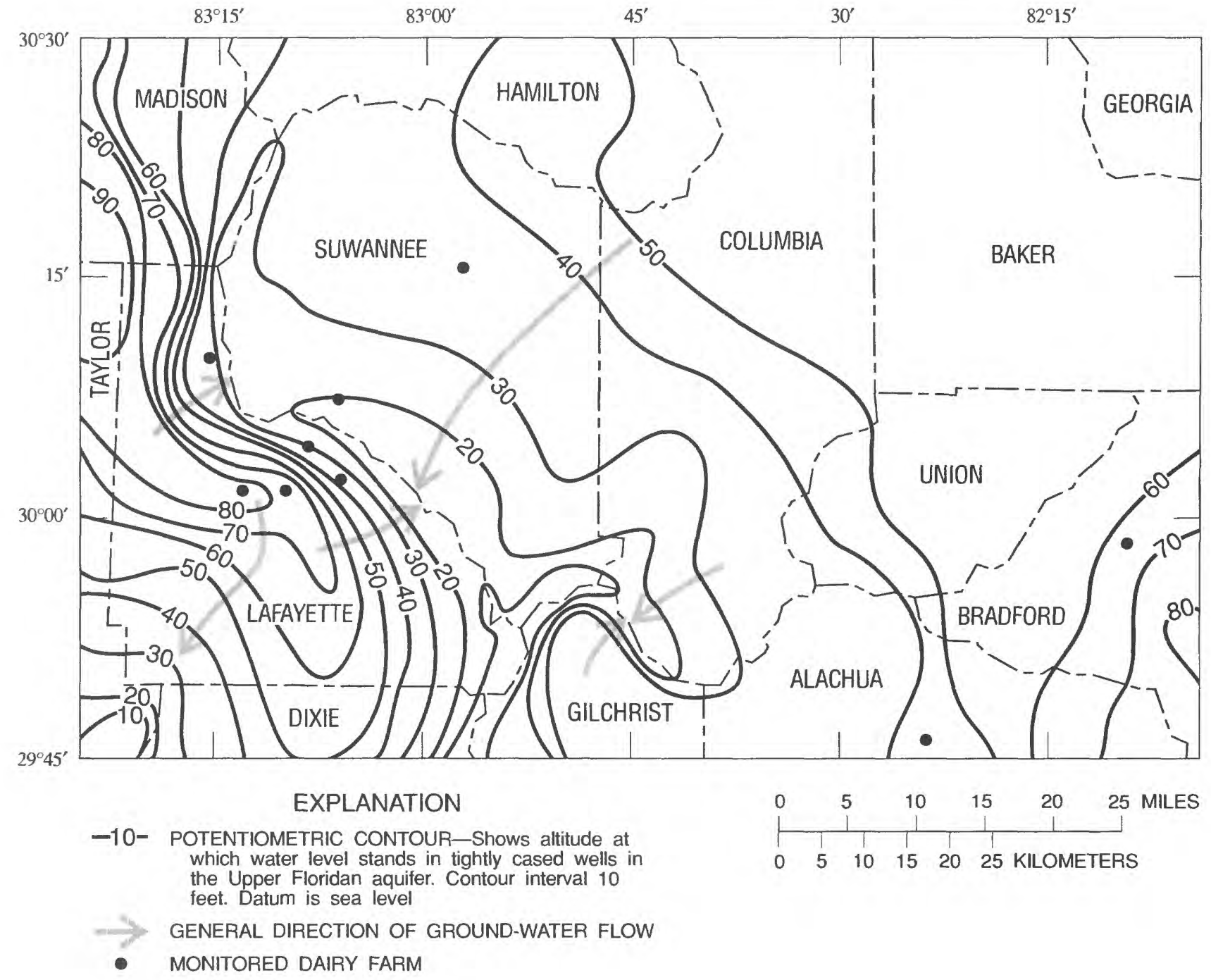

Figure 6. Potentiometric-surface contours and directions of ground-water flow of the Upper Floridan aquifer in the study area, May 1990. (Modified from Meadows, 1991.)

cement. After the cement had set, the rest of the hole was drilled through the cement and into the consolidated rock using a 3-3/4 in. diameter tricone rotary bit. Bentonite mud was circulated during drilling to remove cuttings. Where drilling-mud circulation could not be maintained, potable water was used as a drilling fluid. After rotary holes were drilled to at least $10 \mathrm{ft}$ below the water table, 2 -in. diameter, schedule 80 PVC-threaded casing tipped with $10-\mathrm{ft}$ capped PVC screens were placed inside the grouted 4-in. diameter casings. The 2 -in. screen was packed with sand topped with a layer of hydrated bentonite pellets and the 2-in. casing was grouted within the 4 -in. casing.
As soon as possible after drilling, wells were developed by surging with compressed air. Well development was continued until specific conductance of the produced water was stable and turbidity was minimized.

\section{Collection and Analysis of Water Samples}

Samples were collected from three sources during the study: wastewater lagoons, monitoring wells, and dairy farm supply wells. All sampling sites were sampled quarterly for 1 year. Selected sampling wells were sampled monthly 
(app. II). Because of a drought during most of the sampling period and the lack of natural ponds or streams on the dairy farms, too few samples of ephemeral surface-water bodies were collected to provide a representative data set.

Lagoon samples were collected by immersing sample bottles in the fluid parts of the lagoons, until the bottles were filled. Before collection of samples from monitoring wells, the wells were purged by bailing with a sterilized PVC bailer until at least three standing casing volumes of water had been removed and specific conductance of the bailed water had stabilized. Supply wells were allowed to flow through flamed wellhead spigots for at least 15 minutes, until temperature and specific conductance had stabilized, before samples were collected.

Field measurements made at the time of sampling included water level (in monitoring wells only), $\mathrm{pH}$, temperature, and specific conductance. Counts of fecal coliform and fecal streptococcal bacteria were made in the field using the membrane-filter method (Britton and Greeson, 1987). Constituents measured at the Quality of Water Service Unit in Ocala, Florida, using standard USGS analytical methods (Fishman and Friedman, 1989) included dissolved concentrations of: chloride, sulfate, potassium, phosphorus, nitrite plus nitrate nitrogen, nitrite nitrogen, and ammonium nitrogen; and total concentrations of ammonium plus organic nitrogen, and phosphorus.

\section{Data Analysis}

To examine the migration of dairy waste leachate from the land surface to shallow ground water to deeper ground water, the water-quality data was grouped for statistical analysis as follows: wastewater lagoons (representing waste leachate), shallow ground water from monitoring wells, and deeper ground water from supply wells on the dairy farms. To investigate the effects that varying hydrogeologic settings might have on the leaching of dairy cow wastes to ground water, the water-quality data from the shallow monitoring wells was grouped according to the source of the water: surficial aquifer, Upper Floridan aquifer, and intermediate confining unit. To examine the effects of land uses on dairy farms on shallow ground-water quality, the water-quality data from shallow monitoring wells was grouped according to the land use adjacent to or in which the monitoring wells were located. Monitored land uses on the dairy farms included: intensive areas, intensive pastures, wastewater lagoons, wastewater spray fields, and low-density pastures.

As with most environmental data, mean values in this data set are upwardly skewed by high outlying values, so median values are more representative of the data than means; thus, median values are used to compare and contrast data. Data ranges are illustrated using box plots of selected chemical constituents for the three data-analysis groupings. Censored data (concentrations below analytical detection limits) are integrated with the rest of the data and statistics are computed using the log probability regression method (Helsel and Cohn, 1988).

Table 2. Monitoring-well characteristics

[ICU, intermediate confining unit; SA, surficial aquifer; UFA, Upper Floridan aquifer]

\begin{tabular}{ccc}
$\begin{array}{c}\text { Well } \\
\text { number }\end{array}$ & $\begin{array}{c}\text { Depth } \\
\text { (in feet) }\end{array}$ & Land use $\quad$ Hydrogeologlc unit \\
\hline
\end{tabular}

\begin{tabular}{|c|c|c|c|}
\hline $1-1$ & 18 & Lagoon & ICU \\
\hline $1-2$ & 18 & Low-density pasture & ICU \\
\hline $1-3$ & 13 & Lagoon & ICU \\
\hline $1-4$ & 23 & Sprayfield & $\mathrm{ICU}$ \\
\hline $2-1$ & 28 & Lagoon & $\mathrm{ICU}$ \\
\hline $2-2$ & 23 & Intensive pasture & $\mathrm{ICU}$ \\
\hline $2-3$ & 19 & Intensive pasture & ICU \\
\hline $2-4$ & 18 & Low-density pasture & $\mathrm{ICU}$ \\
\hline $2-S$ & 70 & Barn & $\mathrm{ICU}$ \\
\hline $3-1$ & 20 & Low-density pasture & SA \\
\hline $3-2$ & 18 & Lagoon & SA \\
\hline $3-3$ & 35 & Intensive area & SA \\
\hline $3-4$ & 24 & Sprayfield & $\mathrm{SA}$ \\
\hline $4-1$ & 50 & Lagoon & SA \\
\hline $4-2$ & 34 & Intensive pasture & UFA \\
\hline 4-3 & 50 & Low-density pasture & UFA \\
\hline $4-4$ & 48 & Sprayfield & UFA \\
\hline $4-S$ & 80 & Barn & UFA \\
\hline $5-1$ & 25 & Lagoon & SA \\
\hline $5-2$ & 20 & Intensive area & SA \\
\hline $5-3$ & 15 & Intensive area & SA \\
\hline $5-S$ & 65 & Bam & UFA \\
\hline $6-1$ & 48 & Lagoon & UFA \\
\hline $6-2$ & 48 & Low-density pasture & UFA \\
\hline $6-3$ & 46 & Low-density pasture & UFA \\
\hline $6-4$ & 48 & Sprayfield & UFA \\
\hline $7-1$ & 44 & Intensive area & UFA \\
\hline $7-2$ & 45 & Low-density pasture & UFA \\
\hline $7-3$ & 39 & Lagoon & UFA \\
\hline $7-4$ & 48 & Low-density pasture & UFA \\
\hline $7-S$ & 75 & Barn & UFA \\
\hline $8-1$ & 40 & Lagoon & UFA \\
\hline $8-2$ & 35 & Lagoon & UFA \\
\hline $8-3$ & 50 & Intensive area & UFA \\
\hline $8-4$ & 43 & Low-density pasture & UFA \\
\hline $8-S$ & 80 & Barn & UFA \\
\hline $9-1$ & 100 & Low-density pasture & UFA \\
\hline $9-2$ & 74 & Lagoon & UFA \\
\hline $9-4$ & 123 & Low-density pasture & UFA \\
\hline 9-S & 150 & Barn & UFA \\
\hline
\end{tabular}

${ }^{1}$ The first number sequentially indicates the dairy farm; the second number sequentially indicates the well ( $\mathrm{S}$ indicates supply well). 


\section{ANALYSIS OF WATER-QUALITY DATA BY WATER SOURCE}

The first of the three data-analysis groupings in this report is based on water source. Three types of water sources were sampled and analyzed during the study: dairy farm wastewater lagoons, shallow ground water (top $10 \mathrm{ft}$ of the saturated zone) from monitoring wells (some of which are adjacent to wastewater lagoons), and deeper ground water from supply wells (which were generally $20-40 \mathrm{ft}$ deeper than the monitoring wells) on selected dairy farms.

\section{Wastewater Lagoons}

Liquid from three dairy farm wastewater lagoons was sampled to examine the composition of leachate from dairy cow waste. The number of samples, maximimum and minimum values, means, and medians of temperature, specific conductance, $\mathrm{pH}$, total ammonium plus organic nitrogen, total phosphorus, and dissolved concentrations of nitrite plus nitrate nitrogen, nitrite nitrogen, ammonium nitrogen, phosphorus, potassium, chloride, sulfate, and counts of fecal coliform and streptococcal bacteria from wastewater lagoons at dairy farms sites 1,3 , and 4 are given in table 3. Wastewater from the dairy farm lagoons had substantially higher median concentrations of ammonium nitrogen $(160 \mathrm{mg} / \mathrm{L})$, ammonium nitrogen plus organic nitrogen (230 mg/L), total phosphorus ( $44 \mathrm{mg} / \mathrm{L}$ ), dissolved phosphorus $(25 \mathrm{mg} / \mathrm{L})$, and potassium $(200 \mathrm{mg} / \mathrm{L})$ than are typically found in ground water in the study area. Concentrations of fecal coliform and streptococcal bacteria were also high in lagoon fluids, with median counts in the hundreds of thousands of colonies per $100 \mathrm{~mL}$. Because of reducing conditions in lagoons, nitrate had a very low median concentration (less than $0.1 \mathrm{mg} / \mathrm{L}$ ) in lagoon liquid compared to the median concentration of ammonium ( $160 \mathrm{mg} / \mathrm{L})$.

Median values and ranges of the analyzed constituents nitrite plus nitrate nitrogen, ammonium nitrogen, potassium, and chloride for the samples collected from wastewater lagoons are shown in figure 7 . The relatively narrow ranges between the 25th and 75th percentiles for these constituents and the lack of values more than 1.5 times the interquartile range for wastewater samples mean that the wastewater lagoons sampled during the study were closely clustered about the median values, with relatively few outlying values.

\section{Shallow Ground Water}

Because the first ground-water to intercept leachate from the land surface is the water immediately below the water table, monitoring wells were installed into the top $10 \mathrm{ft}$

Table 3. Water-quality statistics for wastewater lagoons

$\left[{ }^{\circ} \mathrm{C}\right.$, degree Celsius; $\mu \mathrm{S} / \mathrm{cm}$, microsiemens per centimeter; $\mathrm{mg} / \mathrm{L}$, milligrams per liter; $\mathrm{col} / 100 \mathrm{~mL}$, colonies per 100 milliliters]

\begin{tabular}{|c|c|c|c|c|c|}
\hline $\begin{array}{l}\text { Water-quality property } \\
\text { or constituent and unit } \\
\text { of measurement }\end{array}$ & $\begin{array}{l}\text { Number of } \\
\text { samples }\end{array}$ & Maximum & Minimum & Mean & Median \\
\hline Temperature $\left({ }^{\circ} \mathrm{C}\right)$ & 6 & 26.0 & 16.0 & 20.7 & 21.0 \\
\hline $\begin{array}{c}\text { Specific conductance } \\
\left(\mu \mathrm{S} / \mathrm{cm} \text { at } 25^{\circ} \mathrm{C}\right)\end{array}$ & 9 & 4,080 & 994 & 2.820 & 2,940 \\
\hline pH (standard unit) & 9 & 7.8 & 6.6 & 7.1 & 7.1 \\
\hline $\begin{array}{l}\text { Dissolved nitrite plus } \\
\text { nitrate nitrogen ( } \mathrm{mg} / \mathrm{L} \text { ) }\end{array}$ & 9 & .13 & .04 & .08 & .07 \\
\hline Dissolved nitrite nitrogen ( $\mathrm{mg} / \mathrm{L}$ ) & 9 & .04 & .01 & .03 & .03 \\
\hline $\begin{array}{l}\text { Total ammonium plus } \\
\text { organic nitrogen (mg/L) }\end{array}$ & 9 & 490 & 120 & 260 & 230 \\
\hline $\begin{array}{l}\text { Dissolved ammonium } \\
\text { nitrogen }(\mathrm{mg} / \mathrm{L})\end{array}$ & 9 & 230 & 22.0 & 150 & 160 \\
\hline Total phosphorus (mg/L) & 9 & 66 & 28 & 45 & 44 \\
\hline Dissolved phosphorus $(\mathrm{mg} / \mathrm{L})$ & 8 & 50 & .15 & 23 & 25 \\
\hline Dissolved potassium (mg/L) & 8 & 350 & 44 & 200 & 200 \\
\hline Dissolved chloride $(\mathrm{mg} / \mathrm{L})$ & 9 & 120 & 25 & 60 & 50 \\
\hline Dissolved sulfate $(\mathrm{mg} / \mathrm{L})$ & 9 & 160 & 11 & 42 & 30 \\
\hline Fecal coliform (col/100 mL) & 8 & 870,000 & 4,000 & 343,000 & 130,000 \\
\hline Fecal streptococcal (col/100 mL) & 8 & $2,110,000$ & 56,000 & 514,000 & 255,000 \\
\hline
\end{tabular}


A. DISSOLVED NITRITE + NITRATE NITROGEN

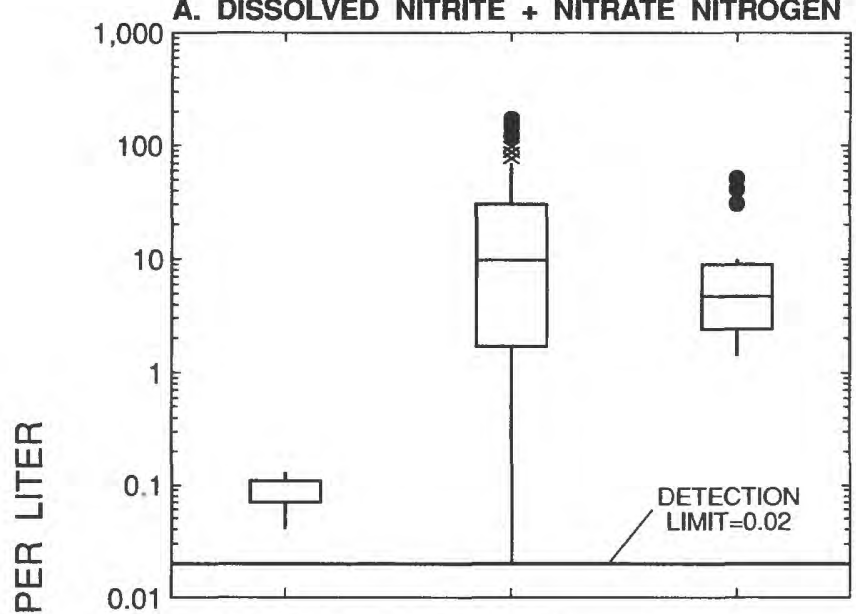

C. DISSOLVED POTASSIUM

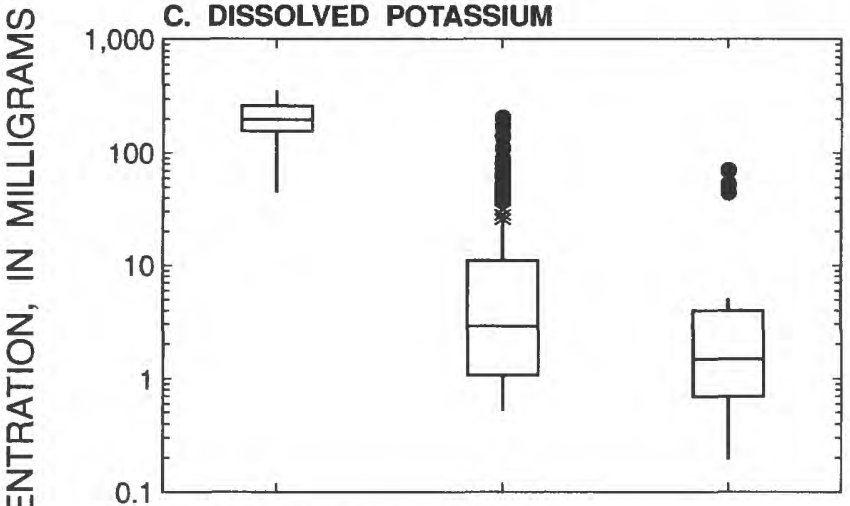

D. DISSOLVED CHLORIDE

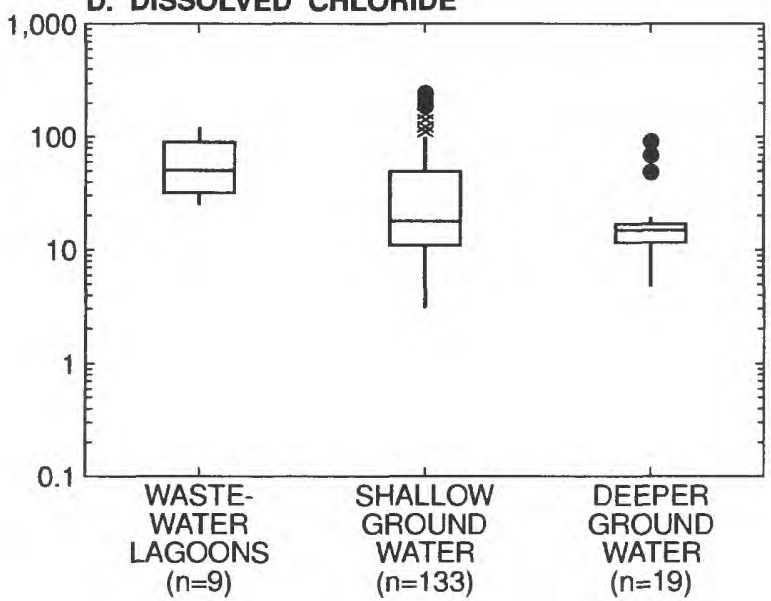

B. DISSOLVED AMMONIUM NITROGEN

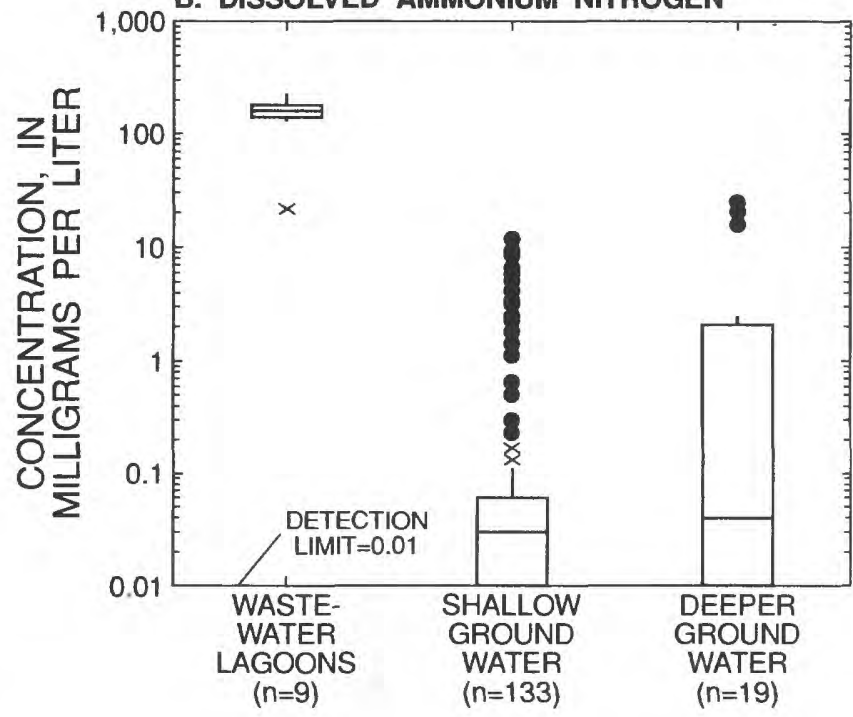

\section{EXPLANATION}

More than 3 times the interquartile range from the 75-percentile value

1.5 to 3 times the interquartile range from the 75 -percentile value

Less than 1.5 times the interquartile range from the 75 -percentile value

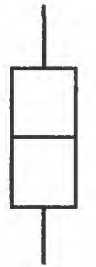

75-percentile value

Median value

25-percentile value

Less than 1.5 times the interquartile range from the 25-percentile value

$\times \quad 1.5$ to 3 times the interquartile range from the 25 -percentile value

$(n=19) \quad$ NUMBER OF SAMPLES

Figure 7. Concentrations of dissolved (A) nitrite plus nitrate nitrogen, (B) ammonium nitrogen, (C) potassium, and (D) chloride in waters from each sample source.

of the saturated zone, to investigate the quality of the ground water that is most likely to have contamination from dairy cow waste leachate. Table 4 lists the number of samples, maximum and minimum values, means, and medians of the physical properties and chemical constituents analyzed in shallow ground-water samples from the 34 dairy farm monitoring wells.
The median dissolved nitrite plus nitrate nitrogen concentration in shallow ground water was $9.8 \mathrm{mg} / \mathrm{L}$, slightly below the primary drinking water standard of $10 \mathrm{mg} / \mathrm{L}$. Nitrite plus nitrate nitrogen occurred in higher concentrations in ground water than in wastewater from lagoons because of the opportunity for nitrification as water flows through the oxidized unsaturated zone to the ground-water table. 
Table 4. Water-quality statistics for shallow ground water

$\left[{ }^{\circ} \mathrm{C}\right.$, degree Celsius; $\mu \mathrm{S} / \mathrm{cm}$, microsiemens per centimeter; $\mathrm{mg} / \mathrm{L}$, milligrams per liter; $<$, less than; $\mathrm{col} / 100 \mathrm{~mL}$, colonies per 100 milliliters]

\begin{tabular}{|c|c|c|c|c|c|}
\hline $\begin{array}{l}\text { Water-quality property } \\
\text { or constituent and unit } \\
\text { of measurement }\end{array}$ & $\begin{array}{l}\text { Number of } \\
\text { samples }\end{array}$ & Maximum & Minimum & Mean & Median \\
\hline Temperature $\left({ }^{\circ} \mathrm{C}\right)$ & 124 & 25.0 & 18.5 & 22.4 & 22.5 \\
\hline $\begin{array}{l}\text { Specific conductance } \\
\left(\mu \mathrm{S} / \mathrm{cm} \text { at } 25^{\circ} \mathrm{C}\right)\end{array}$ & 131 & 2,500 & 95 & 623 & 505 \\
\hline $\mathrm{pH}$ (standard unit) & 132 & 8.0 & 4.0 & 6.5 & 6.7 \\
\hline $\begin{array}{l}\text { Dissolved nitrite plus } \\
\text { nitrate nitrogen }(\mathrm{mg} / \mathrm{L})\end{array}$ & 133 & 140 & .02 & 22 & 9.8 \\
\hline Dissolved nitrite nitrogen $(\mathrm{mg} / \mathrm{L})$ & 133 & .41 & $<.01$ & .03 & .01 \\
\hline $\begin{array}{l}\text { Total ammonium plus } \\
\text { organic nitrogen }(\mathrm{mg} / \mathrm{L})\end{array}$ & 133 & 36 & .20 & 2.2 & 1 \\
\hline $\begin{array}{l}\text { Dissolved ammonium } \\
\text { nitrogen }(\mathrm{mg} / \mathrm{L})\end{array}$ & 133 & 11 & $<.01$ & .59 & .03 \\
\hline Total phosphorus (mg/L) & 133 & 100 & .09 & 8 & 3 \\
\hline Dissolved phosphorus (mg/L) & 99 & 1.2 & $<.01$ & .17 & .09 \\
\hline Dissolved potassium (mg/L) & 133 & 180 & .50 & 16 & 2.9 \\
\hline Dissolved chloride (mg/L) & 133 & 200 & 3.1 & 38 & 18 \\
\hline Dissolved sulfate $(\mathrm{mg} / \mathrm{L})$ & 133 & 110 & .20 & 14 & 10 \\
\hline Fecal coliform (col/100 mL) & 133 & 69,000 & $<10$ & 1,600 & 6 \\
\hline Fecal streptococcal (col/100 mL) & 132 & 13.000 & $<10$ & 340 & 20 \\
\hline
\end{tabular}

The median specific conductance, and the median concentrations of ammonium nitrogen, ammonium plus organic nitrogen, total and dissolved phosphorus, potassium, chloride, and sulfate were much lower in shallow ground water than in wastewater lagoons. The ranges of dissolved nitrite plus nitrate nitrogen, dissolved ammonium nitrogen, dissolved potassium, and dissolved chloride in shallow ground water from monitoring wells are shown in box plots in figure 7 . The greater ranges between the 75th and 25th percentiles and the large amount of data above 1.5 times the interquartile range, compared to those in wastewater samples, indicate that processes such as dispersion, dilution, and differing hydrogeologic source units and land uses cause a wider range of values of the analyzed properties and constituents in shallow ground water than in wastewater lagoons.

The median dissolved phosphorus concentration (0.09 $\mathrm{mg} / \mathrm{L}$ ) was much lower than the median total phosphorus concentration $(3.0 \mathrm{mg} / \mathrm{L})$ in shallow ground water. The relatively high median concentration of total phosphorus in shallow ground water may be due to the occurrence of phospliatic particles or colloidal particles of iron or calcium phosphates in water from the aquifers sampled. Fecal bacteria occurred sporadically in shallow ground-water samples, but generally at counts of less than $20 \mathrm{col} / 100 \mathrm{~mL}$.

\section{Deeper Ground Water}

To examine the quality of deeper ground water, dairy farm supply wells, which are 20 to $40 \mathrm{ft}$ deeper than the monitoring wells, were sampled at dairy farm sites 2, 4, 5, 7 , 8 and 9 (table 5). Median concentrations of most of the analyzed constituents were less in deeper ground water than in shallow ground water. Lower concentrations of most of the analyzed constituents in deeper ground water may be due to dilution, dispersion, adsorption, and denitrification of nutrient-enriched ground water as it percolates through the saturated zone. Fecal bacteria were generally not detected in deeper ground-water samples.

The median concentrations of sulfate and ammonium nitrogen in deeper ground water were nearly identical to those in shallow ground water. The only measured physical property with a greater median value in deeper ground water than in shallow ground water was $\mathrm{pH}$ (7.4 compared to 6.7 for shallow ground water).

In deeper ground-water samples, the dissolved concentrations of nitrite plus nitrite nitrogen, ammonium nitrogen, potassium and chloride were more densely clustered around their medians than in shallow ground water (fig. 7) Ammonium nitrogen had a greater range of concentrations in deeper ground water than in shallow ground water. 
The effect of dilution and dispersion on the concentrations of some measured constituents with increasing depth from the land surface is demonstrated by the sequential decline in the median concentration of chloride and potassium from wastewater lagoons, to shallow ground water, to deeper ground water (fig. 7).

\section{ANALYSIS OF GROUND-WATER QUALITY DATA BY HYDROGEOLOGIC UNITS}

Because waste-management practices are similar on many of the nine dairy farms, it is possible to scrutinize the effect of hydrogeologic settings on shallow ground-water quality on the nine dairy farms by grouping the data according to the three hydrogeologic units tapped by monitoring wells on the nine dairy farms: a surficial aquifer, an intermediate confining unit and the Upper Floridan aquifer.

\section{Surficial Aquifer}

Monitoring wells that tap the surficial aquifer are located in the southwestern part of the study area, principally at dairy farm sites 3 and 5 (fig. 4 and table 2). Median concentrations of dissolved nitrite plus nitrate nitrogen (29 $\mathrm{mg} / \mathrm{L})$, dissolved ammonium plus organic nitrogen $(1.5 \mathrm{mg} / \mathrm{L})$, dissolved potassium $(11 \mathrm{mg} / \mathrm{L})$, and dissolved chloride (39 $\mathrm{mg} / \mathrm{L}$ ) in shallow ground water from the surficial aquifer were higher than in shallow ground water from the Upper Floridan aquifer and the intermediate confining unit (table 6).

Box plots of concentrations of nitrite plus nitrite nitrogen, and dissolved phosphorus in shallow ground water from the surficial aquifer are shown in figure 8. Shallow ground-water samples from the surficial aquifer had the widest range of dissolved nitrite plus nitrate nitrogen and the narrowest range of dissolved phosphorus concentrations of the three hydrogeologic units.

\section{Intermediate Confining Unit}

Monitoring wells that tap the intermediate confining unit were installed on dairy farm sites 1 and 2 in the southeastern part of the study area (fig. 4 and table 2). Shallow ground water from the intermediate confining unit had the lowest median specific conductance $(250 \mu \mathrm{S} / \mathrm{cm})$, the lowest median dissolved concentrations of nitrite plus nitrate nitrogen $(0.17 \mathrm{mg} / \mathrm{L})$, ammonium nitrogen $(0.03 \mathrm{mg} / \mathrm{L})$, potassium $(1.5 \mathrm{mg} / \mathrm{L})$, and sulfate $(3.5 \mathrm{mg} / \mathrm{L})$; and the lowest median concentration of total ammonium plus organic nitrogen $(0.73 \mathrm{mg} / \mathrm{L})$ of the three hydrogeologic units. Shallow ground water from the intermediate confining unit had the highest median concentration of total phosphorus $(12.0 \mathrm{mg} / \mathrm{L})$

Table 5. Water-quality statistics for deeper ground water

${ }^{\circ} \mathrm{C}$, degree Celsius; $\mu \mathrm{S} / \mathrm{cm}$, microsiemens per centimeter; $\mathrm{mg} / \mathrm{L}$, milligrams per liter; $<$, less than; col/100 mL, colonies per 100 milliliters]

\begin{tabular}{|c|c|c|c|c|c|}
\hline $\begin{array}{l}\text { Water-quality property } \\
\text { or constituent and unit } \\
\text { of measurement }\end{array}$ & $\begin{array}{c}\text { Number of } \\
\text { samples }\end{array}$ & Maximum & Minimum & Mean & Median \\
\hline Temperature $\left({ }^{\circ} \mathrm{C}\right)$ & 18 & 25.5 & 21.5 & 22.7 & 22.5 \\
\hline $\begin{array}{l}\text { Specific conductance } \\
\left(\mu \mathrm{S} / \mathrm{cm} \text { at } 25^{\circ} \mathrm{C}\right)\end{array}$ & 19 & 1,320 & 297 & 570 & 478 \\
\hline $\mathrm{pH}$ (standard unit) & 18 & 7.9 & 6.9 & 7.3 & 7.4 \\
\hline $\begin{array}{l}\text { Dissolved nitrite plus } \\
\text { nitrate nitrogen ( } \mathrm{mg} / \mathrm{L} \text { ) }\end{array}$ & 19 & 44 & 1.4 & 10 & 4.7 \\
\hline Dissolved nitrite nitrogen $(\mathrm{mg} / \mathrm{L})$ & 19 & .14 & $<.01$ & .03 & .01 \\
\hline $\begin{array}{l}\text { Total ammonium plus } \\
\text { organic nitrogen (mg/L) }\end{array}$ & 19 & 21 & $<.01$ & 3.8 & .2 \\
\hline $\begin{array}{l}\text { Dissolved ammonium } \\
\text { nitrogen }(\mathrm{mg} / \mathrm{L})\end{array}$ & 19 & 22 & $<.01$ & 3.7 & .04 \\
\hline Total phosphorus (mg/L) & 19 & .06 & $<.01$ & .03 & .03 \\
\hline Dissolved phosphorus (mg/L) & 16 & .05 & $<.01$ & .02 & .01 \\
\hline Dissolved potassium (mg/L) & 19 & 65 & .20 & 10 & 1.5 \\
\hline Dissolved chloride $(\mathrm{mg} / \mathrm{L})$ & 19 & 80 & 4.7 & 31 & 15 \\
\hline Dissolved sulfate (mg/L) & 19 & 24 & .60 & 10 & 10 \\
\hline Fecal coliform (col/100 mL) & 19 & $<1$ & $<1$ & $<1$ & $<1$ \\
\hline Fecal streptococcal (col/100 mL) & 19 & $<1$ & $<1$ & $<1$ & $<1$ \\
\hline
\end{tabular}


Table 6. Median values for physical properties and concentrations of constituents in water from monitoring wells for the three hydrogeologic units sampled

$\left[{ }^{\circ} \mathrm{C}\right.$, degree Celsius; $\mu \mathrm{S} / \mathrm{cm}$, microsiemens per centimeter; $\mathrm{mg} / \mathrm{L}$, milligrams per liter; <, less than; col/100 mL, colonies per 100 milliliters]

\begin{tabular}{|c|c|c|c|}
\hline \multirow{2}{*}{$\begin{array}{l}\text { Water-quality property } \\
\text { or constituent and unit } \\
\text { of measurement }\end{array}$} & \multicolumn{3}{|c|}{$\begin{array}{l}\text { Median value of the indicated hydrogeologic } \\
\text { unit and number of samples ( } n \text { ) }\end{array}$} \\
\hline & $\begin{array}{l}\text { Surficial } \\
\text { aquifer } \\
(n=32)\end{array}$ & $\begin{array}{l}\text { Intermediate } \\
\text { confining unit } \\
\quad(n=31)\end{array}$ & $\begin{array}{c}\text { Upper Floridan } \\
\text { aquifer } \\
(n=70)\end{array}$ \\
\hline Temperature $\left({ }^{\circ} \mathrm{C}\right)$ & 22.0 & 22.0 & 22.5 \\
\hline $\begin{array}{l}\text { Specific conductance } \\
\left(\mu \mathrm{S} / \mathrm{cm} \text { at } 25^{\circ} \mathrm{C}\right)\end{array}$ & 512 & 250 & 592 \\
\hline pH (standard unit) & 5.8 & 6.0 & 7.1 \\
\hline $\begin{array}{l}\text { Dissolved nitrite plus } \\
\text { nitrate nitrogen }(\mathrm{mg} / \mathrm{L})\end{array}$ & 29 & .17 & 9.6 \\
\hline Dissolved nitrite nitrogen $(\mathrm{mg} / \mathrm{L})$ & .02 & $<.01$ & .01 \\
\hline $\begin{array}{l}\text { Dissolved ammonium plus } \\
\text { organic nitrogen }(\mathrm{mg} / \mathrm{L})\end{array}$ & 1.45 & .73 & 1.15 \\
\hline $\begin{array}{l}\text { Dissolved ammonium } \\
\text { nitrogen }(\mathrm{mg} / \mathrm{L})\end{array}$ & .12 & .03 & .02 \\
\hline Total phosphorus (mg/L) & .59 & 12 & 3.6 \\
\hline Dissolved phosphorus (mg/L) & .05 & .23 & .09 \\
\hline Dissolved potassium (mg/L) & 11 & 1.5 & 3.4 \\
\hline Dissolved chloride $(\mathrm{mg} / \mathrm{L})$ & 39 & 33 & 13 \\
\hline Dissolved sulfate $(\mathrm{mg} / \mathrm{L})$ & 7.2 & 3.5 & 14 \\
\hline Fecal coliform $(\mathrm{col} / 100 \mathrm{~mL})$ & $<1$ & 2 & 14 \\
\hline Fecal streptococcal (col/100 mL) & 7 & 55 & 20 \\
\hline
\end{tabular}

and dissolved phosphorus $(0.23 \mathrm{mg} / \mathrm{L})$, and the highest median count $(55 \mathrm{col} / 100 \mathrm{~mL})$ of fecal streptococcal bacteria of the three hydrogeologic units (table 6). High phosphorus concentrations may be due to the presence of phosphatic minerals in the unit. High counts of fecal bacteria in water from this unit may be due to the survival of these bacteria over the relatively short travel distance from the land surface to the water table in this unit (generally $2-10 \mathrm{ft}$.).

Shallow ground water from the intermediate confining unit on dairy farms had the widest distribution of dissolved phosphorus concentrations and the narrowest distribution of dissolved nitrite plus nitrate concentrations of the three hydrogeologic units (fig. 8). The wide range of phosphorus concentrations in ground water from the intermediate confining unit may be due to heterogeneities in phosphorus content of the unit.

\section{Upper Floridan Aquifer}

The unconfined Upper Floridan aquifer is the uppermost hydrogeologic unit at five of the nine monitored dairy farms (fig. 4, table 2). Of the three hydrogeologic units, shallow ground water from the Upper Floridan aquifer had the highest median values of the following analyzed physical properties and chemical constituents: specific conductance $(592 \mu \mathrm{S} / \mathrm{cm}), \mathrm{pH}(7.1 \mathrm{pH}$ units), dissolved sulfate ( $14 \mathrm{mg} / \mathrm{L})$, and fecal coliform bacteria ( $14 \mathrm{col} / 100 \mathrm{ml}$ ) (table 6). Because carbonate rocks of the Upper Floridan are more soluble than the sands and clays of the other units, dissolved solids (indicated by specific conductance) occur in higher concentrations in water from this aquifer, compared to the other two units. Dissolution of calcium carbonate also increases the $\mathrm{pH}$ of water, giving water from this aquifer the highest median $\mathrm{pH}$ (7.1) of the three source units. The higher median sulfate concentration $(14 \mathrm{mg} / \mathrm{L})$ in water from this aquifer may be due to dissolution of gypsum or pyrite, which are common accessory minerals in carbonate aquifers. The median concentrations of dissolved ammonium nitrogen and dissolved chloride in shallow ground water from the Upper Floridan aquifer were the lowest of the three units.

The range of nitrite plus nitrate nitrogen concentrations in shallow ground water from the Upper Floridan aquifer is intermediate between those of the other two units (fig. 8). Dissolved phosphorus concentrations in water from monitoring wells tapping the Upper Floridan clustered much more tightly about the median value (fig. 8) than in water from the other two units. 


\section{EFFECTS OF DAIRY FARM LAND USES ON GROUND-WATER QUALITY}

To analyze the effects of land uses at the dairies on shallow ground-water quality, data from the monitoring wells was grouped according to the type of land use in the area near the monitoring wells (table 2). Land uses in areas adjacent to monitoring wells on the dairy farms include: intensive areas (defoliated areas with great amounts of cow traffic), intensive pastures (high-livestock-density grazing areas), wastewater lagoons, wastewater spray fields, and low-density pastures. It is important to note that the land-use groups have varying numbers of wells tapping each of the three hydrogeologic units discussed previously (table 2).

\section{Intensive Areas}

Shallow ground water from monitoring wells adjacent to intensive areas had the highest median specific conductance $(673 \mu \mathrm{S} / \mathrm{cm})$, and the highest median concentration of nitrite plus nitrate nitrogen $(26 \mathrm{mg} / \mathrm{L})$ of the five land-use groups (table 7). The majority (between the 75 th and 25th percentiles) of the nitrite plus nitrate nitrogen concentrations in shallow ground water near intensive areas were more densely clustered around the median value than for any of the other the five land-use groups (fig. 9).

\section{Intensive Pastures}

Shallow ground water from monitoring wells in intensive pastures had the lowest median $\mathrm{pH}(5.1 \mathrm{pH}$ units) and the highest median concentration of dissolved chloride (48 $\mathrm{mg} / \mathrm{L}$ ) of the five land-use groups. Ranges of the dissolved concentrations of nitrite plus nitrate nitrogen, chloride, and potassium (fig. 9) in shallow ground water beneath intensive pastures were not as variable as those in water from monitoring wells adjacent to the other land-use groups.

\section{Wastewater Lagoons}

Shallow ground water adjacent to wastewater lagoons had the highest median total concentrations of ammonium plus organic nitrogen $(2.1 \mathrm{mg} / \mathrm{L})$, and phosphorus $(4 \mathrm{mg} / \mathrm{L})$; and the highest dissolved median concentrations of phosphorus $(0.10 \mathrm{mg} / \mathrm{L})$, potassium $(17 \mathrm{mg} / \mathrm{L})$, and sulfate $(11 \mathrm{mg} / \mathrm{L})$ of the five land-use groups (table 8). Either because some lagoons were sealed by naturally occurring clays and settled organic solids, or because monitoring wells did not tap leachate plumes from the lagoons, some samples from lagoon wells had low concentrations of the analyzed constituents (wells 2-1, 8-1, 8-2, and 9-2 (app. II)). Conversely, many of the monitoring wells adjacent to lagoons had relatively high concentrations of the analyzed constituents (wells 1-1, 3-2, 4-1, 5-1, 6-1, and 7-3 (app. II). Because of these two situations, there was a great range in the dissolved concentrations of nitrite plus nitrate nitrogen, chloride, and potassium in shallow ground water adjacent to wastewater lagoons (fig. 9).

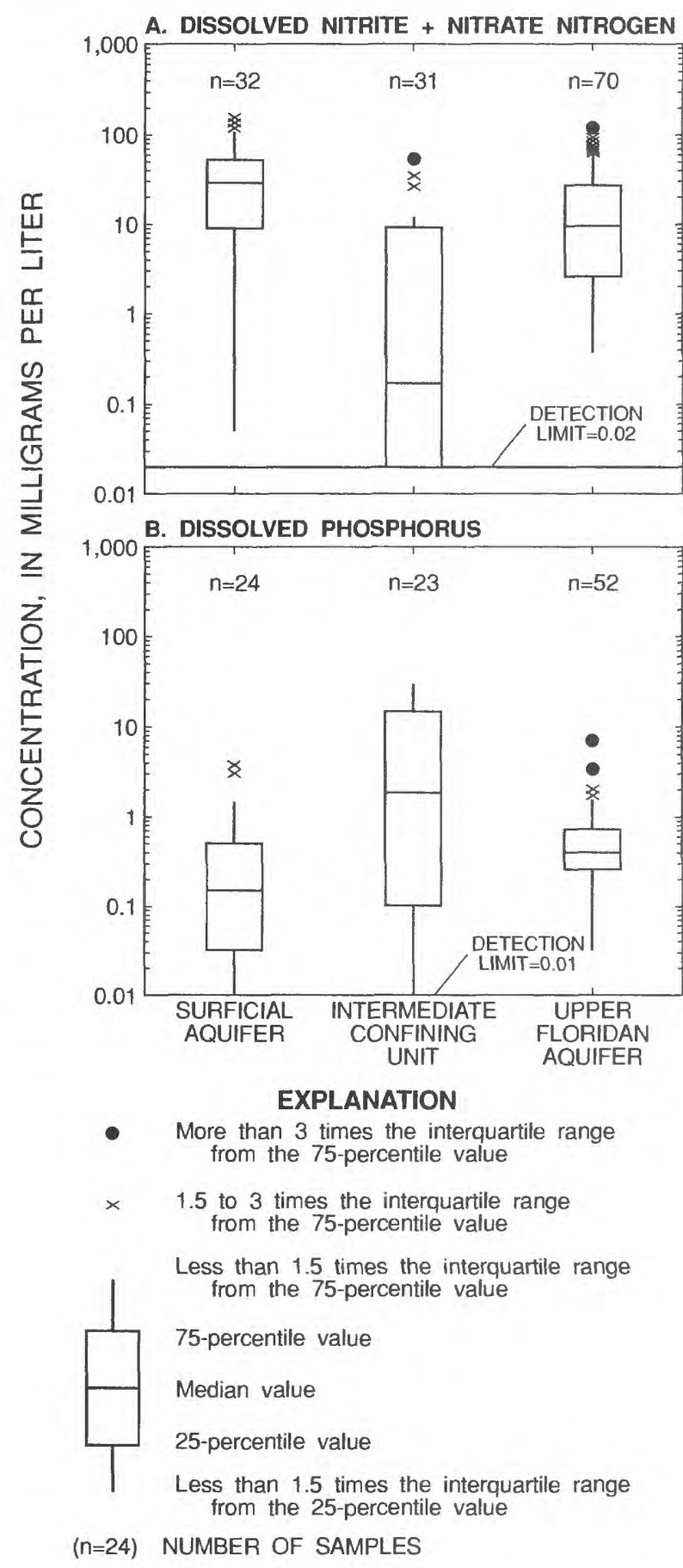

Figure 8. Concentrations of dissolved (A) nitrite plus nitrate nitrogen and $(B)$ phosphorus concentrations in water from each hydrogeologic unit. 
Table 7. Median values for physical properties and concentrations of constituents in water from monitoring wells classified by adjacent land use

$I^{\circ} \mathrm{C}$, degree Celsius; $\mu \mathrm{S} / \mathrm{cm}$, microsiemens per centimeter; $\mathrm{mg} / \mathrm{L}$, milligrams per liter; <, less than; col/100 mL, colonies per 100 milliliters]

\begin{tabular}{|c|c|c|c|c|c|}
\hline \multirow[b]{2}{*}{$\begin{array}{l}\text { Water-quality property } \\
\text { or constituent and unit } \\
\text { of measurement }\end{array}$} & \multicolumn{5}{|c|}{ Median value or concentration for indicated land use and number of samples ( $n$ ) } \\
\hline & $\begin{array}{c}\text { Intensive } \\
\text { area } \\
(\mathrm{n}=20)\end{array}$ & $\begin{array}{l}\text { Intensive } \\
\text { pasture } \\
(n=12)\end{array}$ & $\begin{array}{c}\text { Wastewater } \\
\text { lagoon } \\
(n=43)\end{array}$ & $\begin{array}{l}\text { Wastewater } \\
\text { spray field } \\
(\mathrm{n}=12)\end{array}$ & $\begin{array}{l}\text { Low density } \\
\text { pasture } \\
(\mathrm{n}=42)\end{array}$ \\
\hline Temperature $\left({ }^{\circ} \mathrm{C}\right)$ & 22.5 & 22.5 & 22.5 & 22.5 & 22.5 \\
\hline $\begin{array}{c}\text { Specific conductance } \\
\left(\mu \mathrm{S} / \mathrm{cm} \text { at } 25^{\circ} \mathrm{C}\right)\end{array}$ & 673 & 469 & 614 & 430 & 365 \\
\hline $\mathrm{pH}$ (standard unit) & 6.6 & 5.1 & 6.6 & 7.1 & 7.1 \\
\hline $\begin{array}{l}\text { Dissolved nitrite plus } \\
\text { nitrate nitrogen }(\mathrm{mg} / \mathrm{L})\end{array}$ & 26 & 11 & 11 & 23 & 5.1 \\
\hline Dissolved nitrite nitrogen ( $\mathrm{mg} / \mathrm{L})$ & .01 & $<.01$ & .01 & $<.01$ & $<.01$ \\
\hline $\begin{array}{l}\text { Dissolved ammonium plus } \\
\text { organic nitrogen }(\mathrm{mg} / \mathrm{L})\end{array}$ & 1.1 & .88 & 2.1 & .96 & 1 \\
\hline $\begin{array}{l}\text { Dissolved ammonium } \\
\text { nitrogen }(\mathrm{mg} / \mathrm{L})\end{array}$ & .03 & .02 & .06 & .02 & .02 \\
\hline Total phosphorus (mg/L) & 1.65 & 6 & 4 & 2.6 & 3.2 \\
\hline Dissolved phosphorus (mg/L) & .08 & .05 & .10 & .07 & .09 \\
\hline Dissolved potassium (mg/L) & 2.3 & 6.5 & 17 & 1.4 & 1.6 \\
\hline Dissolved chloride (mg/L) & 36 & 48 & 45 & 16 & 12 \\
\hline Dissolved sulfate $(\mathrm{mg} / \mathrm{L})$ & 8.7 & 5 & 11 & 9.5 & 11 \\
\hline Fecal coliform (col/ $100 \mathrm{~mL}$ ) & 2 & 10 & 8 & 11 & $<1$ \\
\hline Fecal streptococcal $(\mathrm{col} / 100 \mathrm{~mL})$ & 20 & $<1$ & 20 & 6 & 40 \\
\hline
\end{tabular}

\section{Wastewater Spray Fields}

Shallow ground water beneath wastewater spray fields had the lowest median specific conductance $(430 \mu \mathrm{S} / \mathrm{cm})$, the lowest median dissolved potassium concentration $(1.40 \mathrm{mg} / \mathrm{L})$, the highest median fecal coliform count $(11 \mathrm{col} / 100 \mathrm{~mL})$ and the second highest median nitrite plus nitrate nitrogen concentration ( $23 \mathrm{mg} / \mathrm{L}$ ) of the five land-use groups (table 7 ). Ranges of dissolved concentrations of nitrite plus nitrate nitrogen, chloride, and potassium in shallow ground water beneath spray fields were intermediate between the ranges of the other land-use groups.

\section{Low-density Pastures}

Shallow ground water beneath low-density pastures had the lowest median specific conductance $(365 \mu \mathrm{S} / \mathrm{cm})$, the lowest median dissolved concentrations of nirite plus nitrate nitrogen $(5.1 \mathrm{mg} / \mathrm{L})$, and chloride $(12 \mathrm{mg} / \mathrm{L})$; the highest median occurrence of fecal streptococcal bacteria (40 $\mathrm{col} / 100 \mathrm{~mL}$ ), and one of the highest median concentrations of dissolved sulfate $(11 \mathrm{mg} / \mathrm{L})$ of the five land-use groups. The relatively high median concentration of dissolved sulfate and the high median count of fecal streptococcal bacteria may attributed to the fact that 8 of 11 of the low-density pasture monitoring wells tap the unconfined Upper Floridan aquifer, which had the highest median concentration of dissolved sulfate and the second highest median occurrence of fecal streptococcal bacteria of water from the three hydrogeologic units sampled.

\section{SUMMARY AND CONCLUSIONS}

Three dairy farm wastewater lagoons, 34 shallow monitoring wells, and 6 supply wells on 9 dairy farms in north Florida were sampled and analyzed quarterly for 1 year and selected wells were sampled monthly for dissolved nitrogen species, specific conductance, temperature, $\mathrm{pH}$, total phosphorus, dissolved phosphorus, dissolved potassium, dissolved sulfate, dissolved chloride, and fecal bacteria.

To assess changes in leachate from dairy cow waste as it migrates from the land surface to shallow ground water to deeper ground water, water-quality data from dairy farm wastewater lagoons, shallow monitoring wells, and deeper supply wells on dairy farms was compared and contrasted. Liquid from dairy farm wastewater lagoons, composed of dairy cow wastes diluted with supply well water, contained relatively high concentrations of total ammonium plus organic nitrogen, dissolved and total phosphorus, dissolved potassium, dissolved chloride, and fecal bacteria. Shallow 
A. DISSOLVED NITRITE + NITRATE NITROGEN

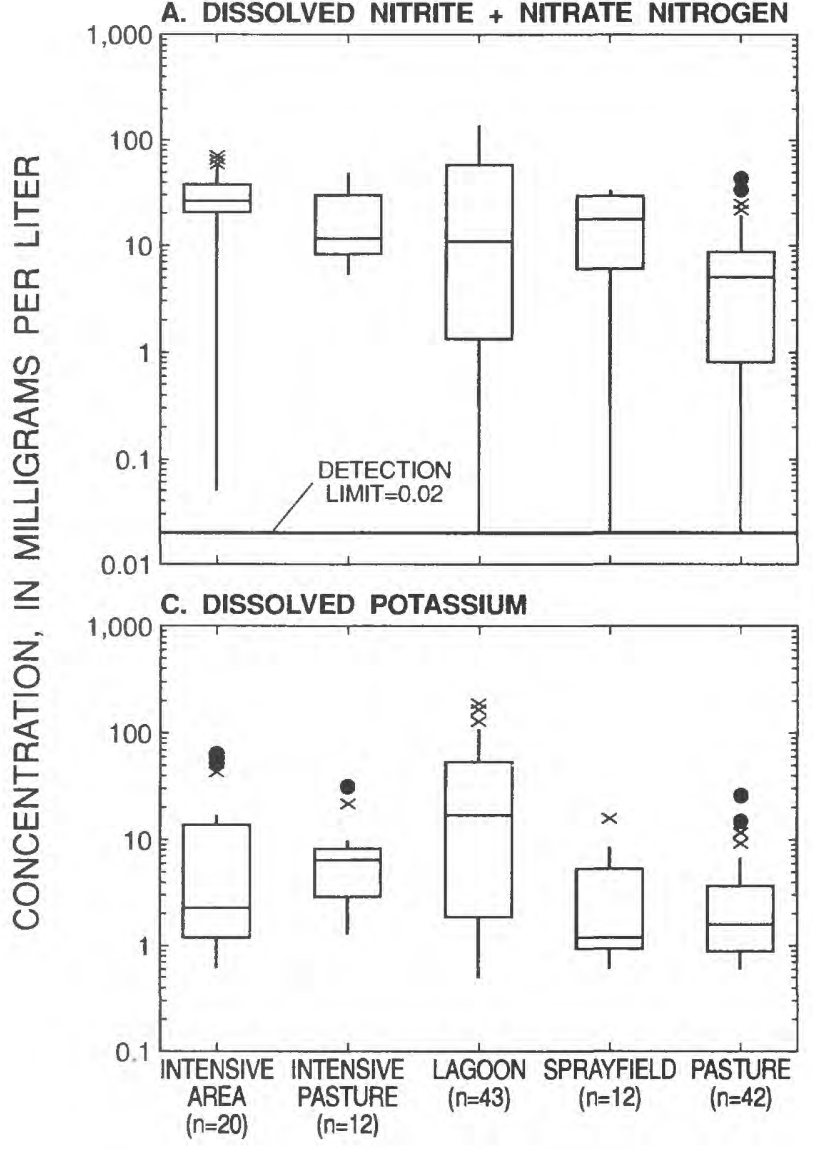

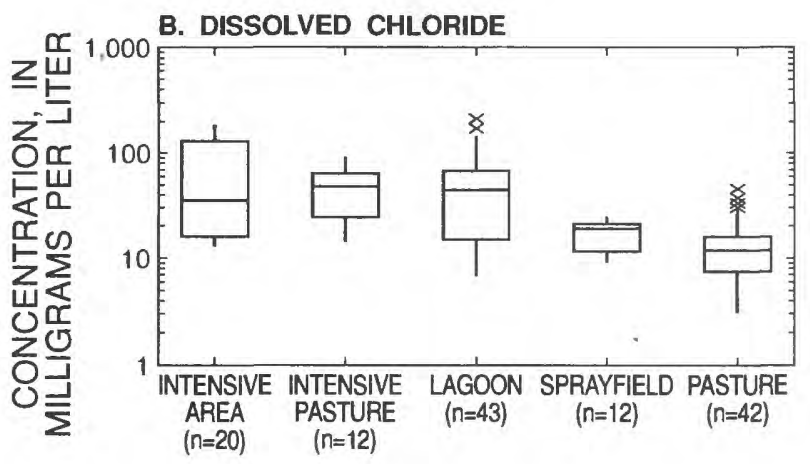

EXPLANATION

- More than 3 times the interquartile range from the 75-percentile value

$\times$

1.5 to 3 times the interquartile range from the 75 -percentile value

Less than 1.5 times the interquartile range from the 75 -percentile value

$\square$

75-percentile value

Median value

25-percentile value

Less than 1.5 times the interquartile range from the 25-percentile value

$(n=42)$ NUMBER OF SAMPLES

Figure 9. Concentrations of dissolved (A) nitrite plus nitrate nitrogen, (B) chloride, and (C) potassium in ground water beneath areas of various dairy farm land uses.

ground water beneath the nine dairy farms had higher median specific conductance, and higher median concentrations of dissolved nitrite plus nitrate nitrogen, dissolved ammonium plus organic nitrogen, total and dissolved phosphorus, dissolved potassium, dissolved chloride, and higher median counts of fecal bacteria than deeper ground water from supply wells on the dairy farms. Declines in the concentrations of these constituents with depth in the saturated zone may be due to dilution, dispersion, adsorption, or denitrification.

To examine the effect of hydrogeologic settings on ground-water quality beneath the nine studied dairies, the shallow ground-water quality data was divided according to the hydrogeologic unit from which the water was derived: an unnamed surficial aquifer, the Upper Floridan aquifer, and the intermediate confining unit. Shallow ground water from the surficial and Upper Floridan aquifers at north Florida dairy farms had elevated median dissolved concentrations of nitrite plus nitrate nitrogen, potassium and sulfate, and and elevated median concentration of total ammonium plus organic nitrogen, relative to shallow ground water in the intermediate confining unit. Shallow ground water from the intermediate confining unit at dairy farms had lower concentrations of the analyzed nutrients except for total and dissolved median phosphorus concentrations, which may have been elevated by naturally occurring phosphatic particles in the unit.

To investigate the effects of dairy farm land uses on shallow ground-water quality, the water-quality data was divided into land-use groups, based on the land use adjacent to or in which the monitoring wells were located. These land-use groups included: intensive areas (defoliated, manure-paved areas where cows are concentrated), intensive pastures (areas where dairy cows are kept at densities of greater than four per acre), wastewater lagoons, wastewater spray fields, and low-density pastures. Near areas where dairy cow wastes are concentrated (intensive areas, intensive pastures, wastewater lagoons), shallow ground water had elevated median specific conductance, and elevated median concentrations of dissolved nitrite plus nitrate nitrogen, potassium, and chloride. Shallow ground water beneath wastewater spray fields had lower median levels of specific conductance and these chemical constituents, except for nitrite plus nitrate nitrogen, which had a median concentration of 23.0 $\mathrm{mg} / \mathrm{L}$ in shallow ground water beneath spray fields. Shallow ground water beneath low-density pastures, where waste loading rates are the lowest of the five land-use groups, generally had the lowest median concentration of the analyzed constituents. 


\section{REFERENCES}

Bashkin, V.N., and Kudeyarov, V.N., 1983, Nitrate content of ground waters in agricultural areas of the Oka River basin: Soviet Soil Science, v. 15, no. 11, p. 41-47.

Britton, L.J., and Greeson, P.E., 1987, Methods for collection and analysis of aquatic biological and microbiological samples: U.S. Geological Survey Techniques of Water-Resources Investigations, book 5, chap. A4, 363 p.

Brooks, H.K., 1981, Geologic map of Florida: Center for Environmental and Natural Resources, Florida Cooperative Extension Service, Institute of Food and Agricultural Sciences, Gainesville, University of Florida, 1 sheet.

Caldwell, R.E., and Johnson, R.W., 1982, General soil map, Florida: U.S. Department of Agriculture, Soil Conservation Service, 1 sheet.

Crane, J.J., 1986, An investigation of the geology, hydrogeology, and hydrochemistry of the lower Suwannee River basin: Florida Bureau of Geology Report of Investigations 96. 203 p.

Fishman, M.J., and Friedman, L.C., 1989, Methods of determination of inorganic substances in water and fluvial sediments: U.S. Geological Survey Techniques of Water-Resources Investigations, book 5, chap. A1, (3d ed.), $545 \mathrm{p}$.

Freeze, R.A., and Cherry, J.A., 1979, Groundwater: Englewood Cliffs, N.J., Prentice-Hall, 604 p.

Grundy, Kevin, 1980, Tackling farm waste: Ipswich, Suffolk, England Farming Press. Limited,

Helsel, D.R., and Cohn, T.A.. 1988, Estimation of descriptive statistics for multiple censored water quality data: Water Resources Research, v. 24 (12), p. 1997-2004.
Lawton, D.E., 1977, Geologic map of Georgia: The Geologic and Water Resources Division, Department of Natural Resources. Atlanta.

Meadows, P.E., 1991, Potentiometric surface of the Upper Floridan aquifer in the Suwannee River Water Management District, Florida: U.S. Geological Survey Open-File Report 90-582, 1 sheet.

Miller, J.A.. 1986, Hydrogeologic framework of the Floridan aquifer system in Florida and in parts of Georgia, Alabama, and South Carolina-Regional Aquifer-System Analysis: U.S. Geological Survey Professional Paper 1403-B, 91 p.

National Research Council, 1978, The health effects of nitrate, nitrite, and N-nitroso compounds: Washington, D.C., National Academy Press.

Scott, T.M., 1983, The Hawthorn Formation of northeastern Florida: Florida Bureau of Geology Report of Investigations $94,90 \mathrm{p}$.

Scragg, R.K.R., Dorsch, M.M., McMichael, A.J., and Baghurst, P.A., 1982, Birth defects and household water supply: The Medical Journal of Australia, v. 2, p. 577-579.

Stewart, J.C., 1990, Drinking water hazards: Hiram, Ohio, Envirographics Publishing, 323 p.

Strange, M., and Krupicka, L., 1984, Farming and cancer, in It's not all sunshine and fresh air: Center for Rural Affairs, p. 41-53.

Vigil, J., Warbuton, S., Haynes, W.S., and Kaiser, L.R., 1965. Nitrates in municipal water supply cause methemoglobinemia in infant: Public Health Report, v. 80, no. 12, p. 119-1121.

Vrba, J., 1981, General aspects of ground-water nonpoint pollution, in Van Duijvenbooden, W., and others, eds., Quality of Ground Water: Proceedings of an international symposium, Studies in Environmental Science, v. 17, The Netherlands, Elsevier Publishing Co. 


\section{APPENDIX I}

Labeled Aerial Photographs of the Nine Monitored Dairy Farms 


\section{DAIRY FARM SITE 1}

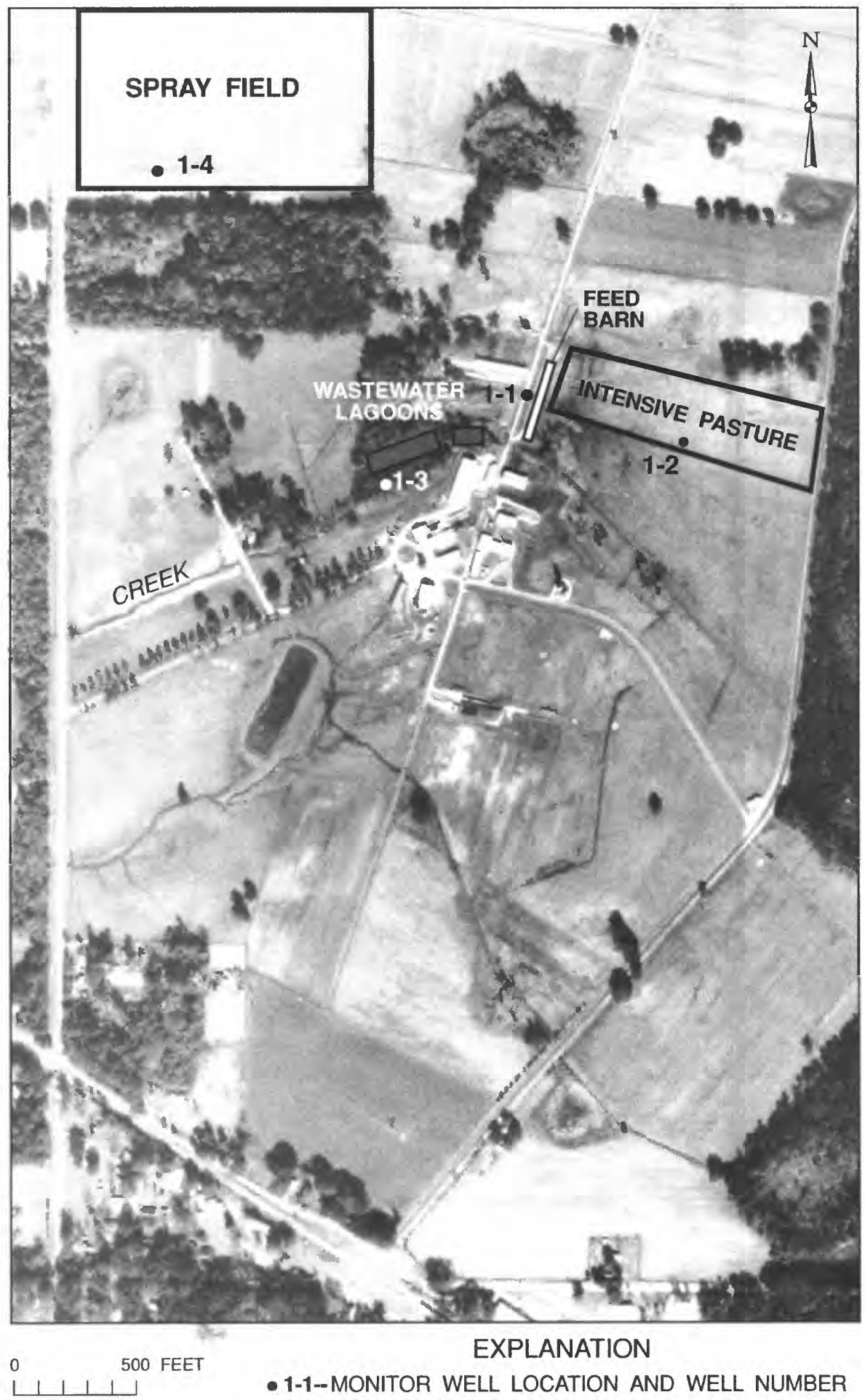




\section{DAIRY FARM SITE 2}
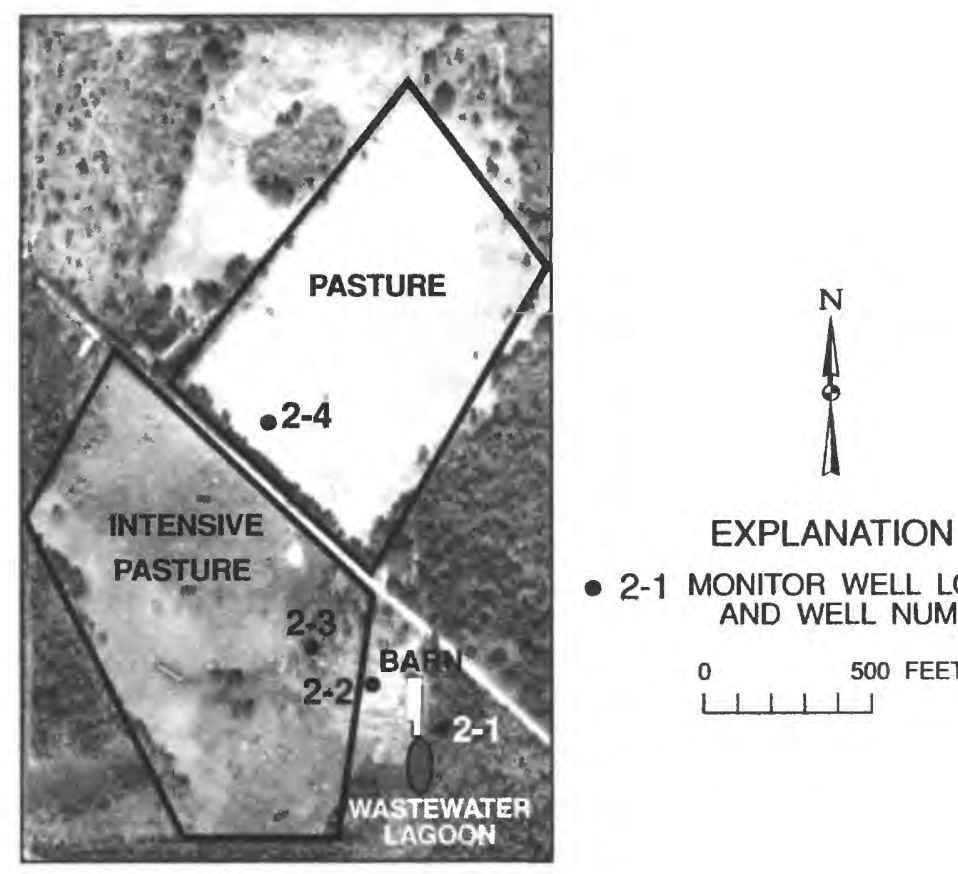

- 2-1 MONITOR WELL LOCATION AND WELL NUMBER

0 500 FEET 
DAIRY FARM SITE 3

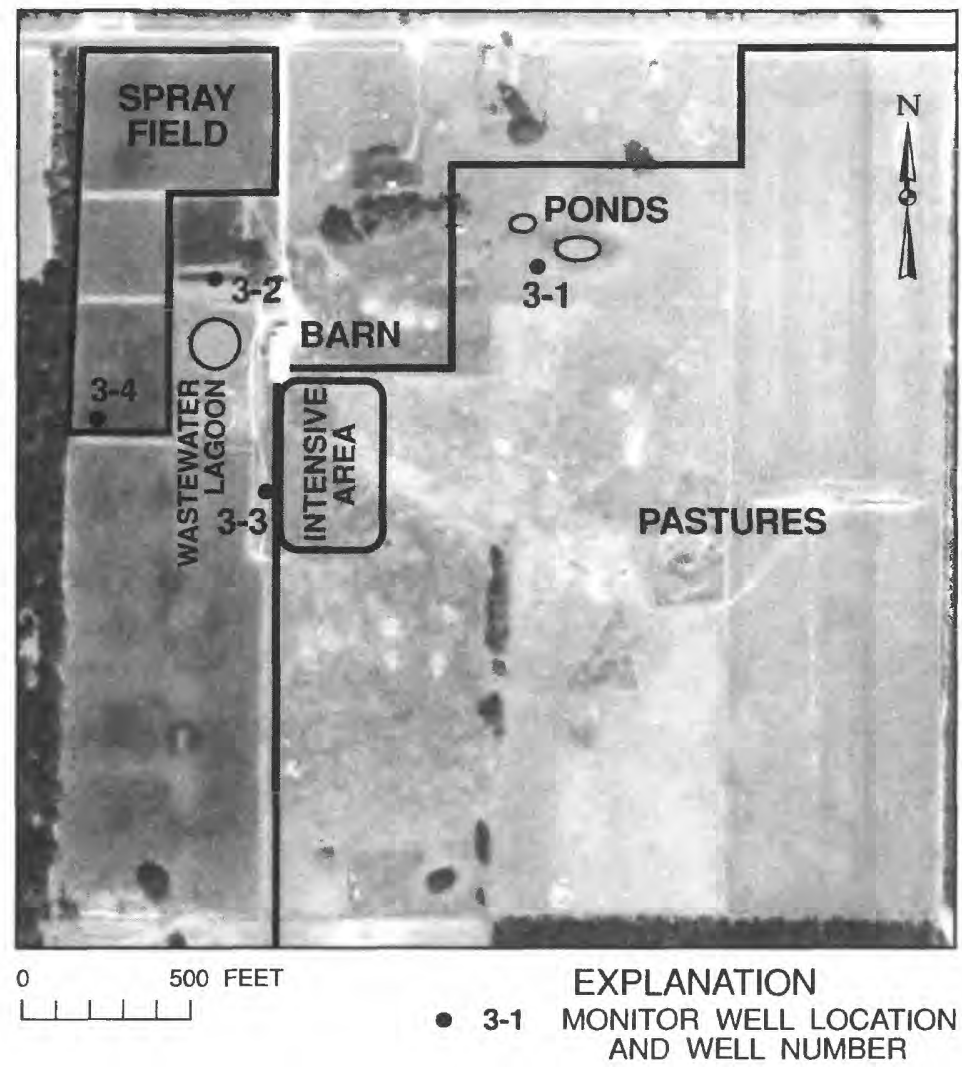


DAIRY FARM SITE 4

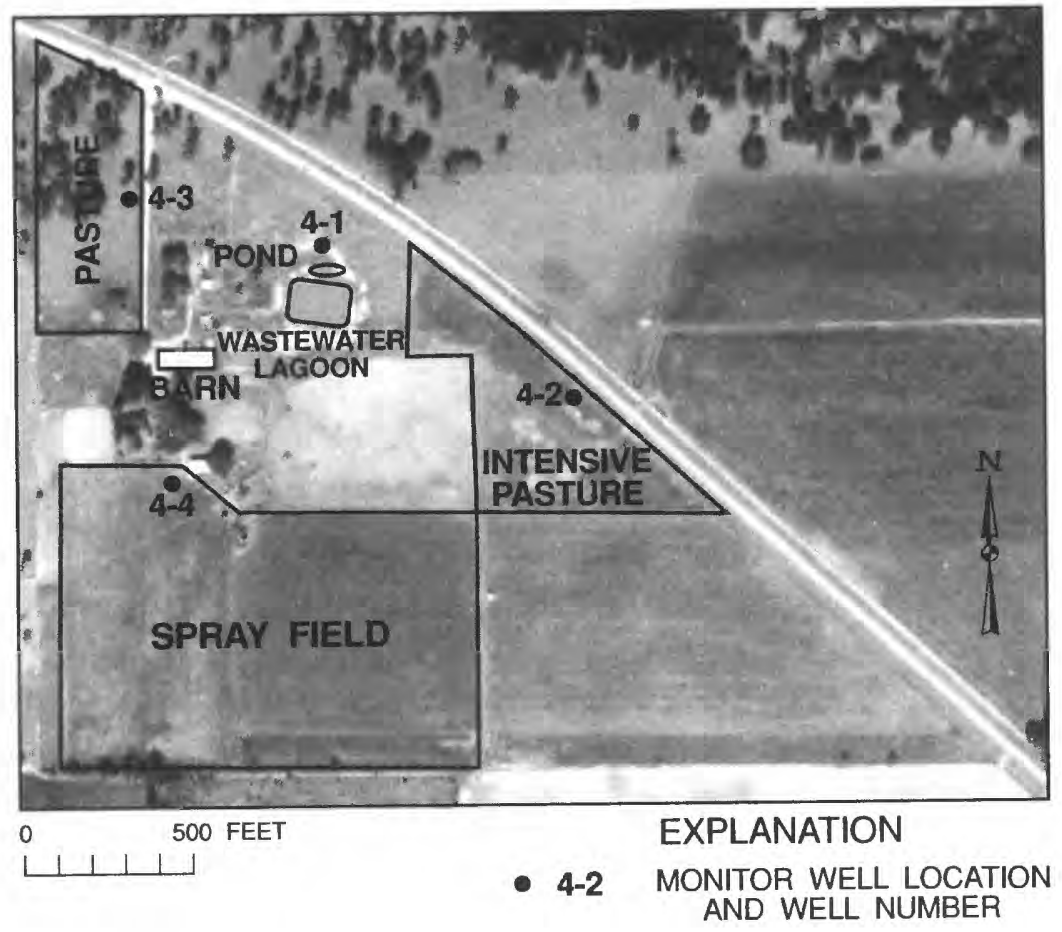


DAIRY FARM SITE 5

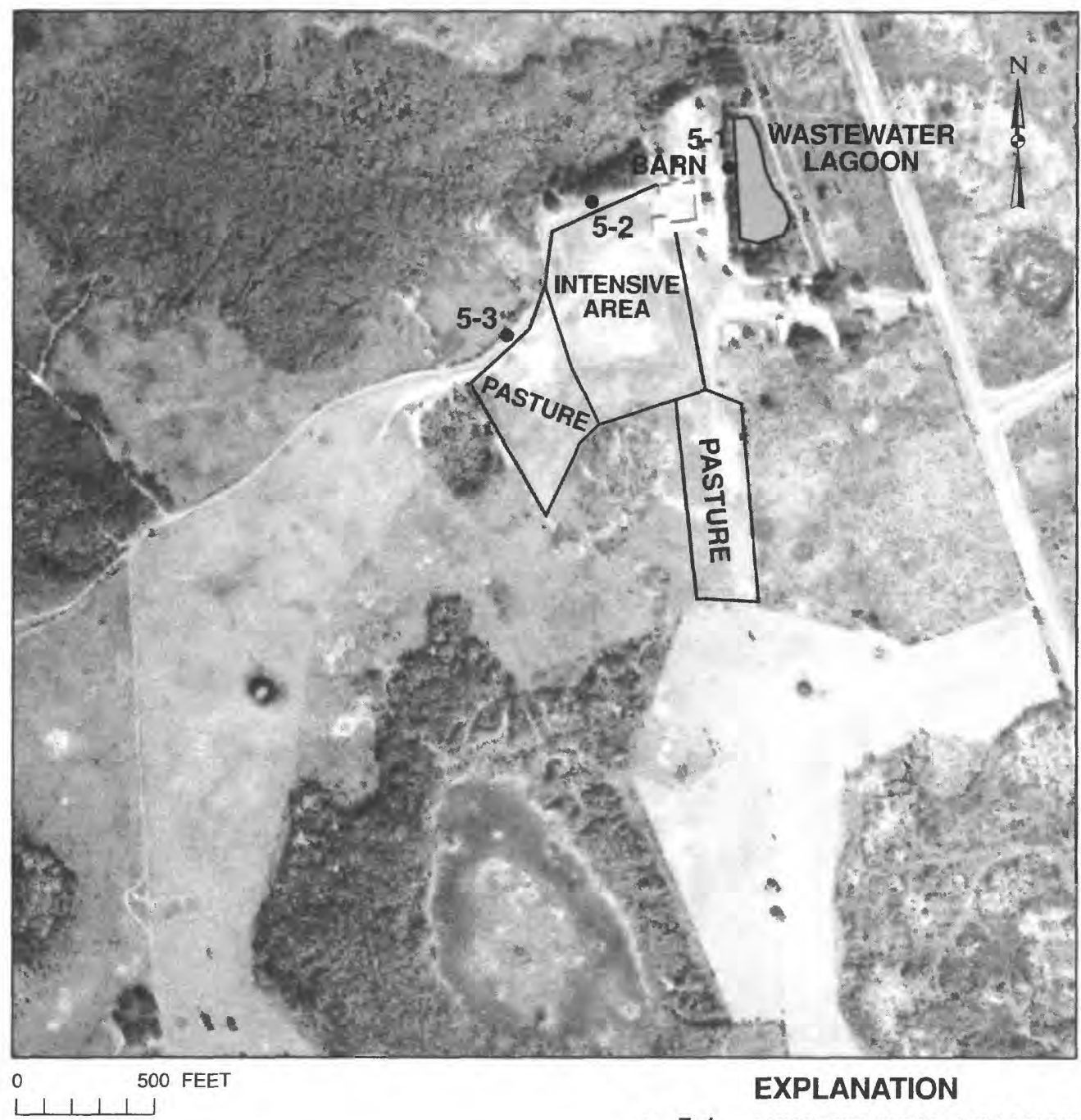

- 5-1 MONITOR WELL LOCATION AND WELL NUMBER 
DAIRY FARM SITE 6

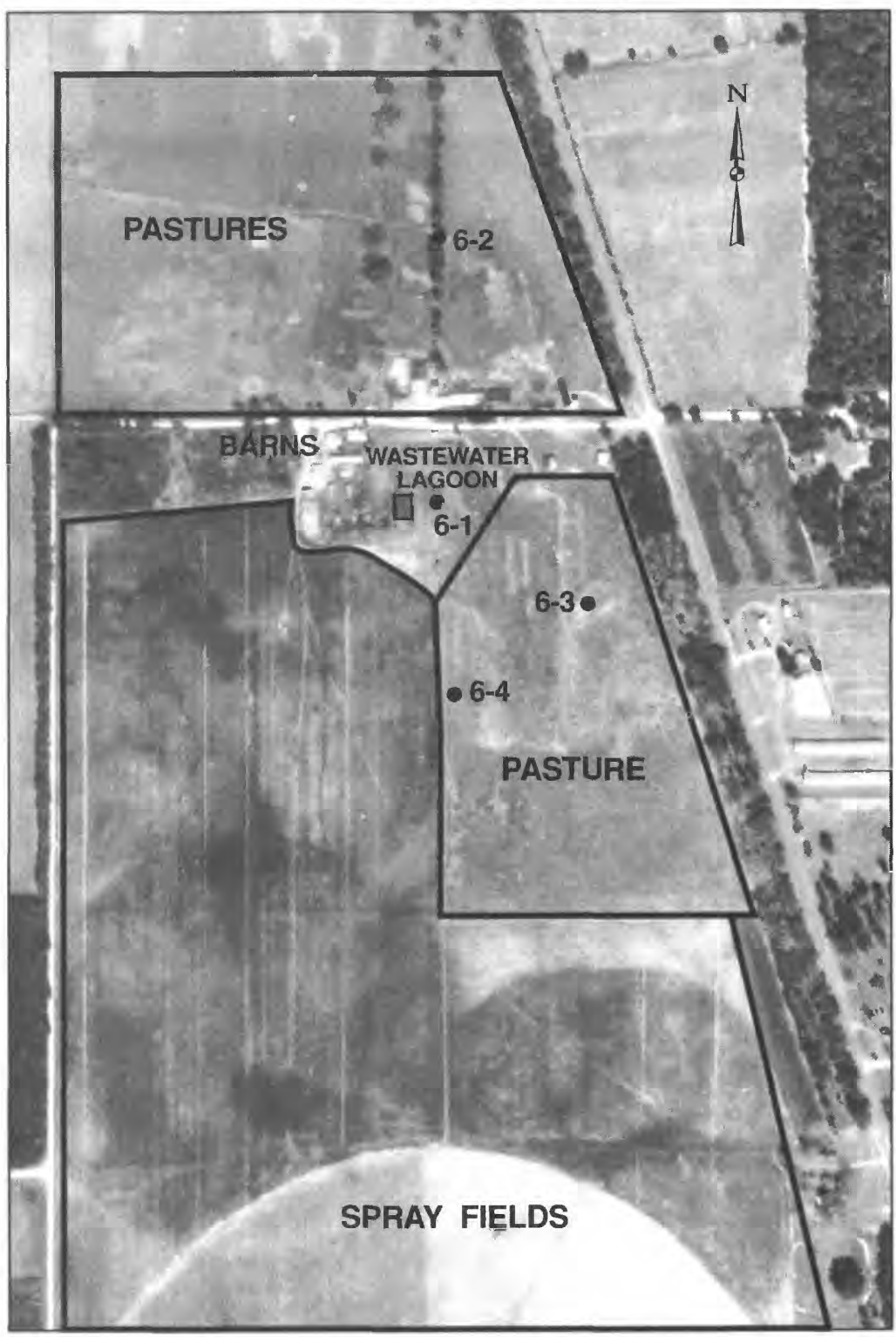

$0 \quad 500$ FEET

EXPLANATION

- 6-1 MONITOR WELL location AND WELL NUMBER 


\section{DAIRY FARM SITE 7}

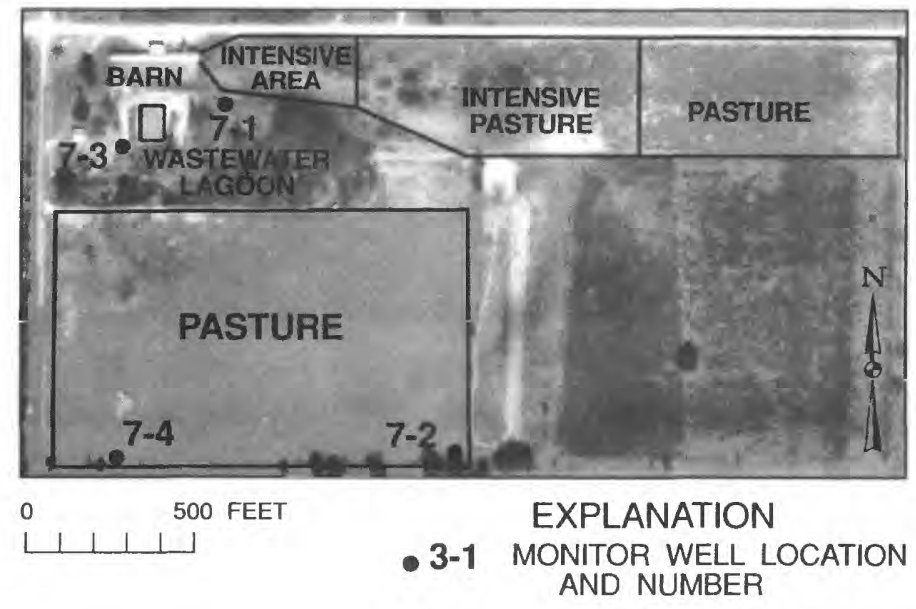

DAIRY FARM SITE 8

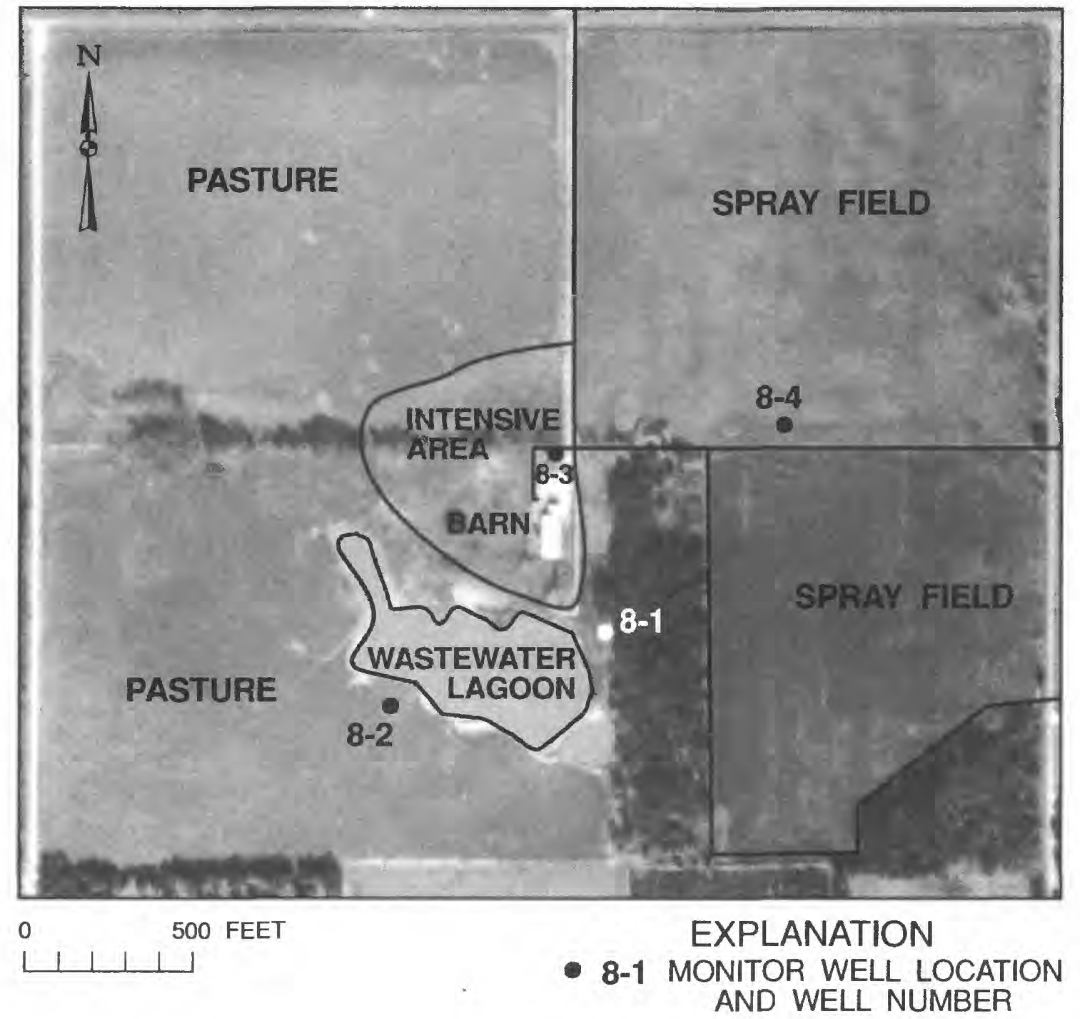


DAIRY FARM SITE 9

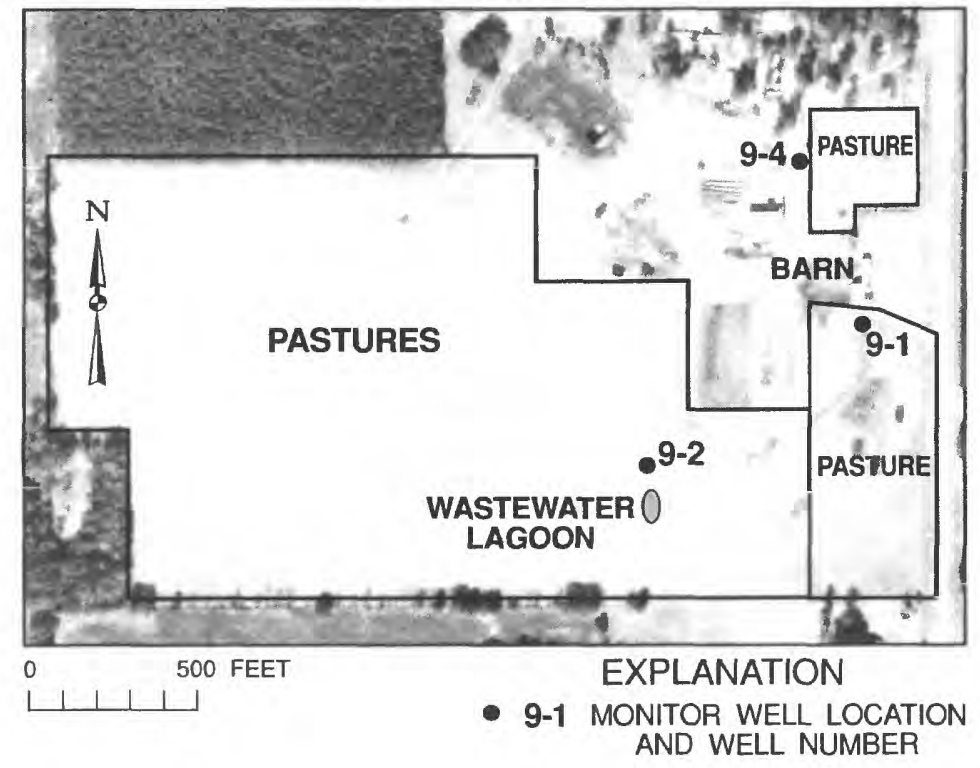


APPENDIX II

Water-Quality Data 


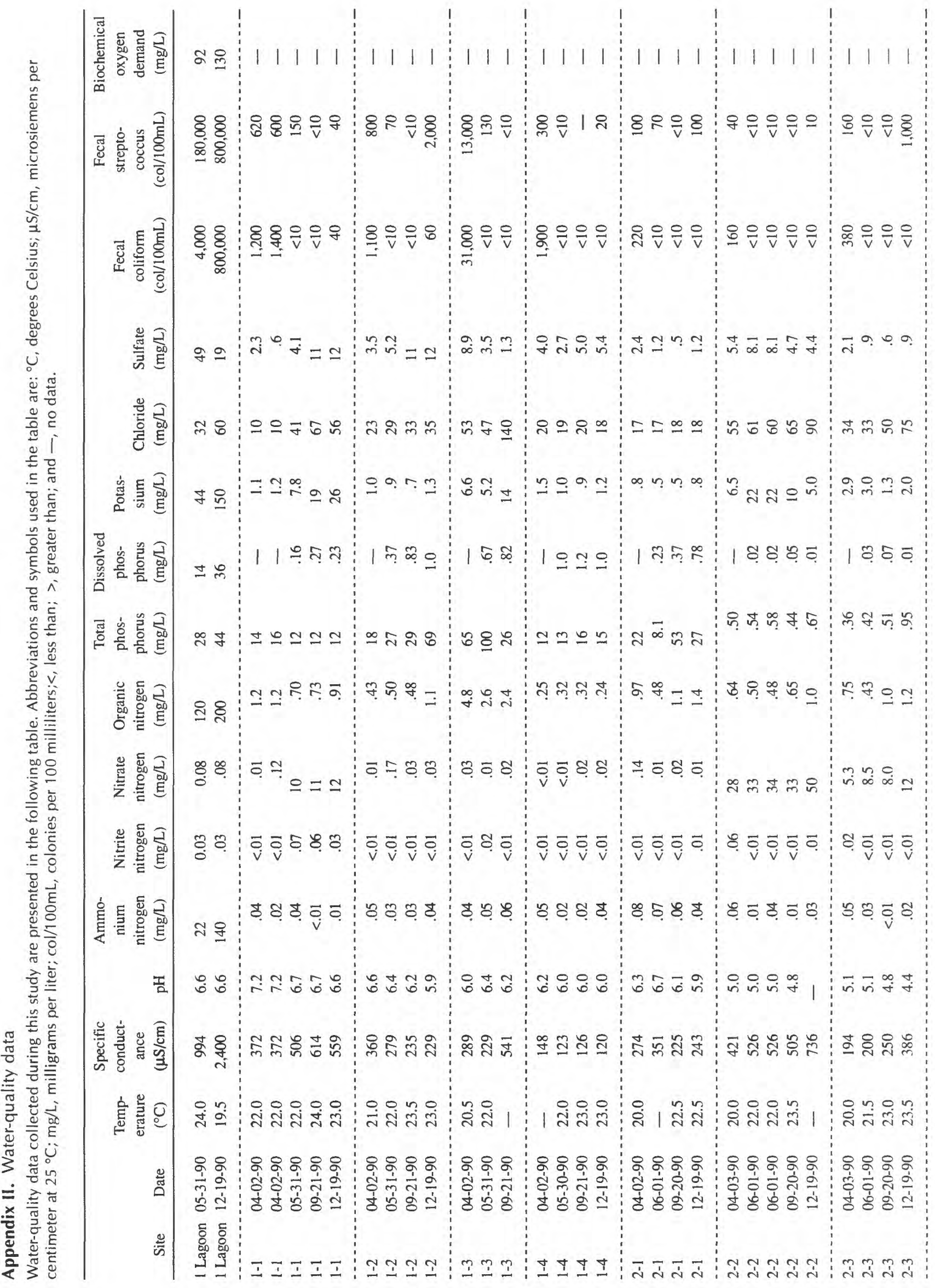




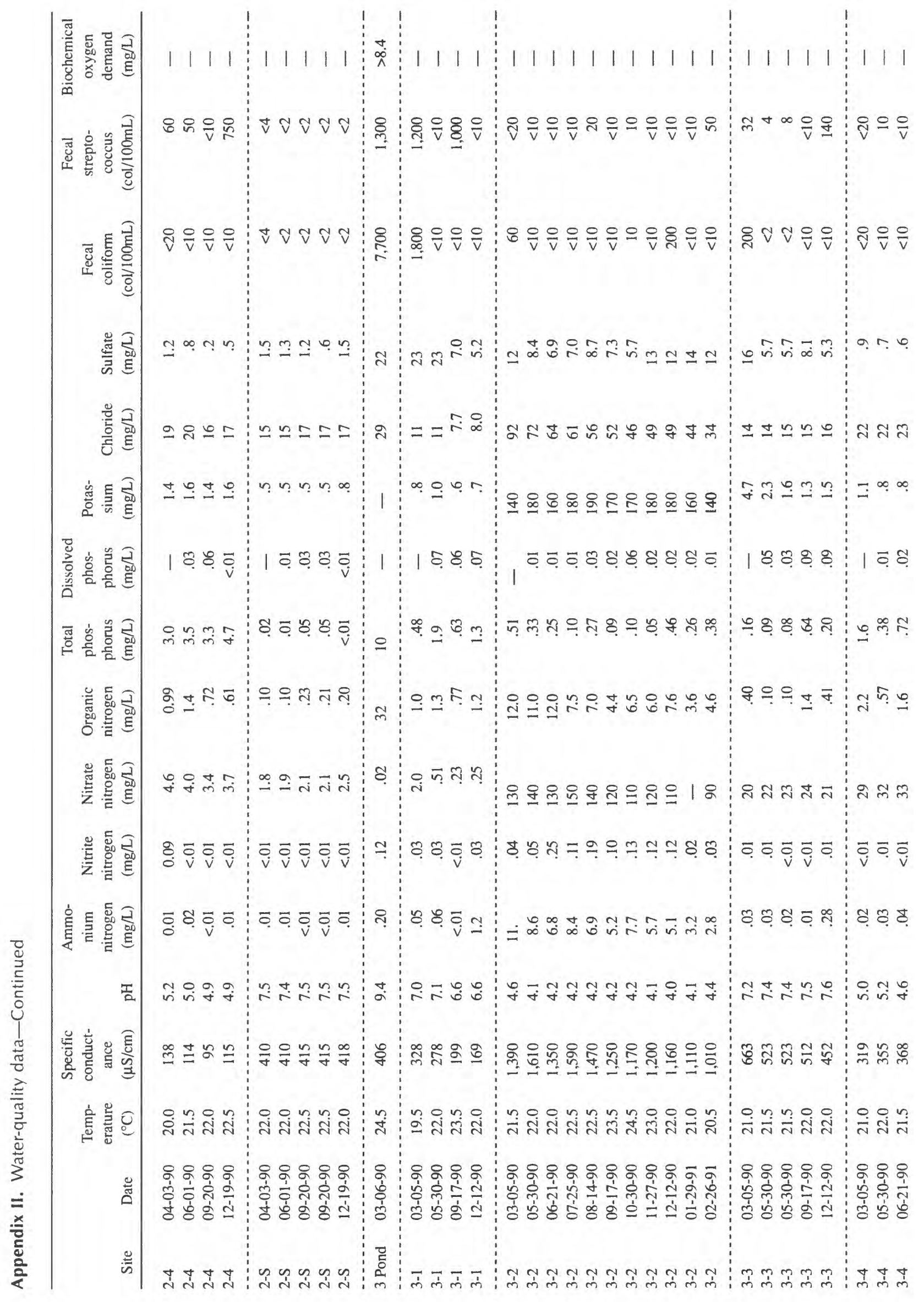




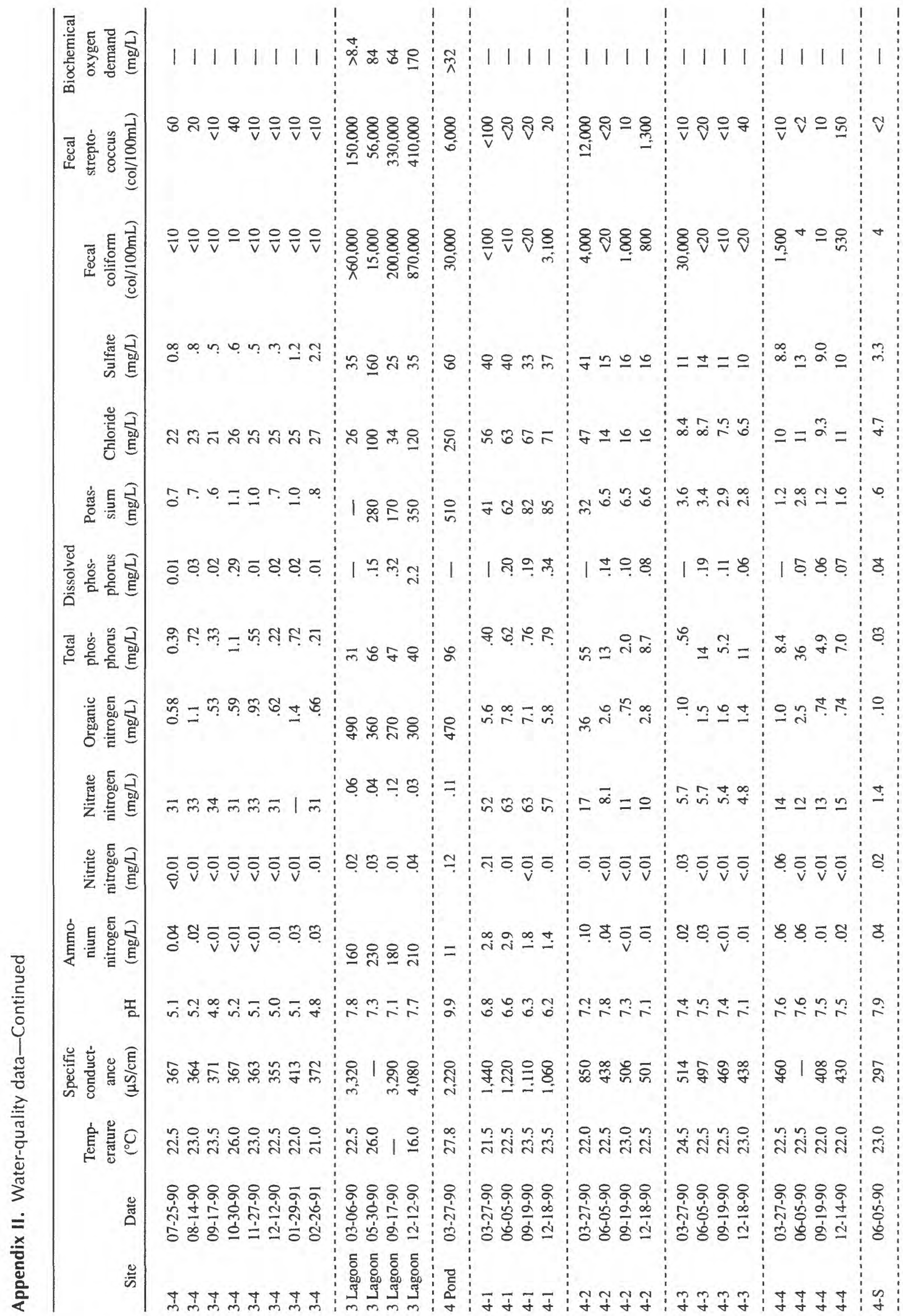




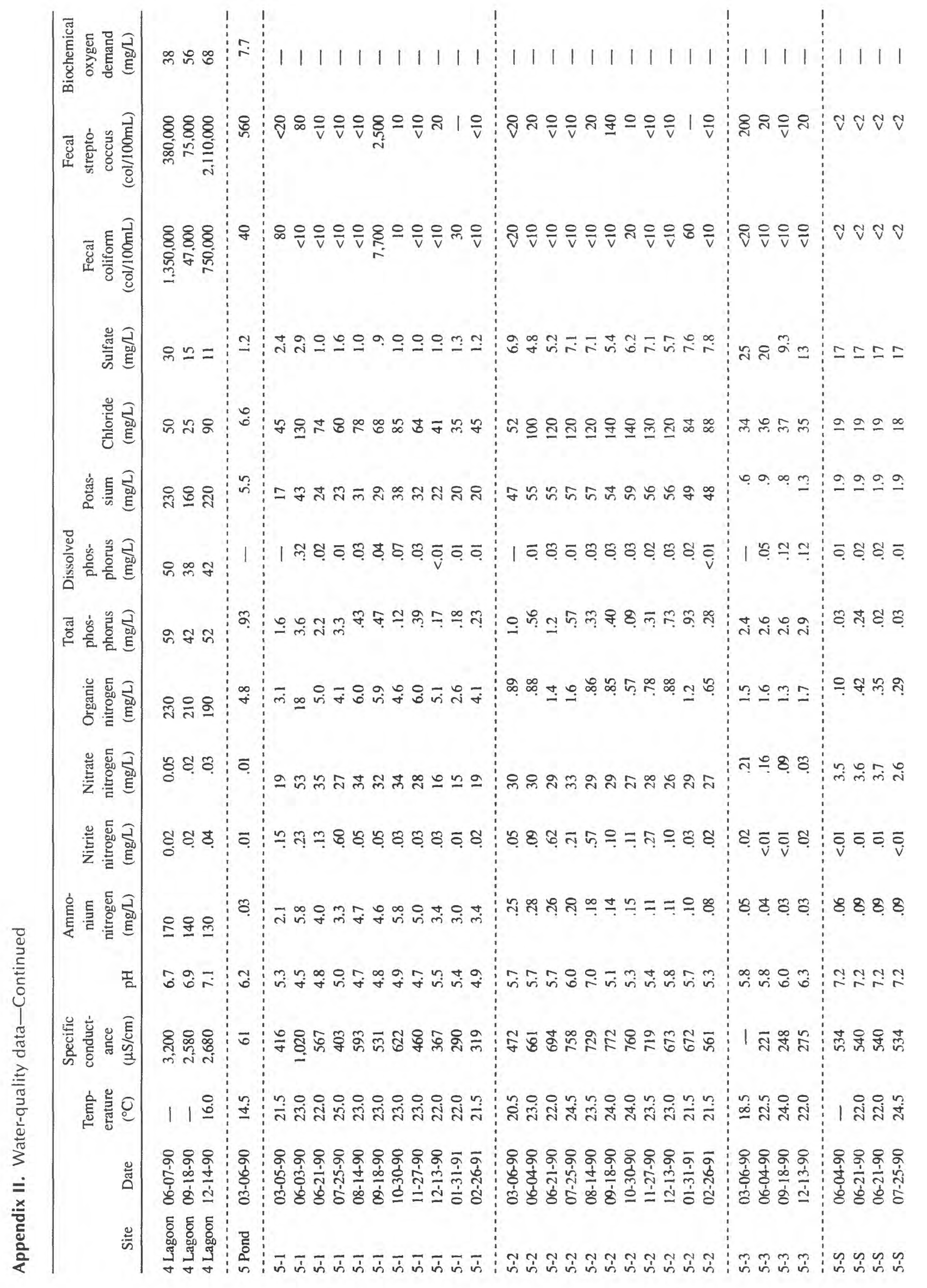




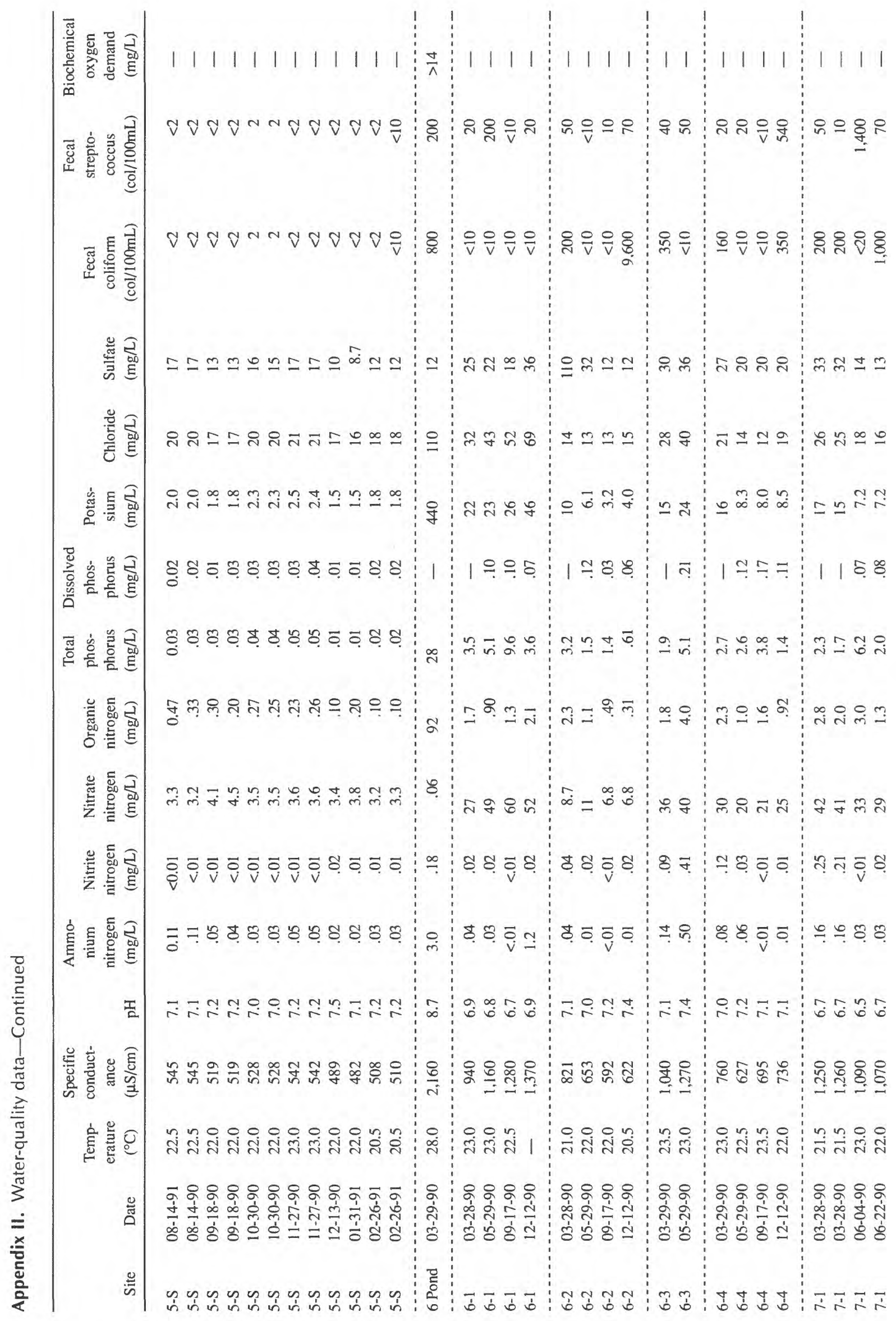




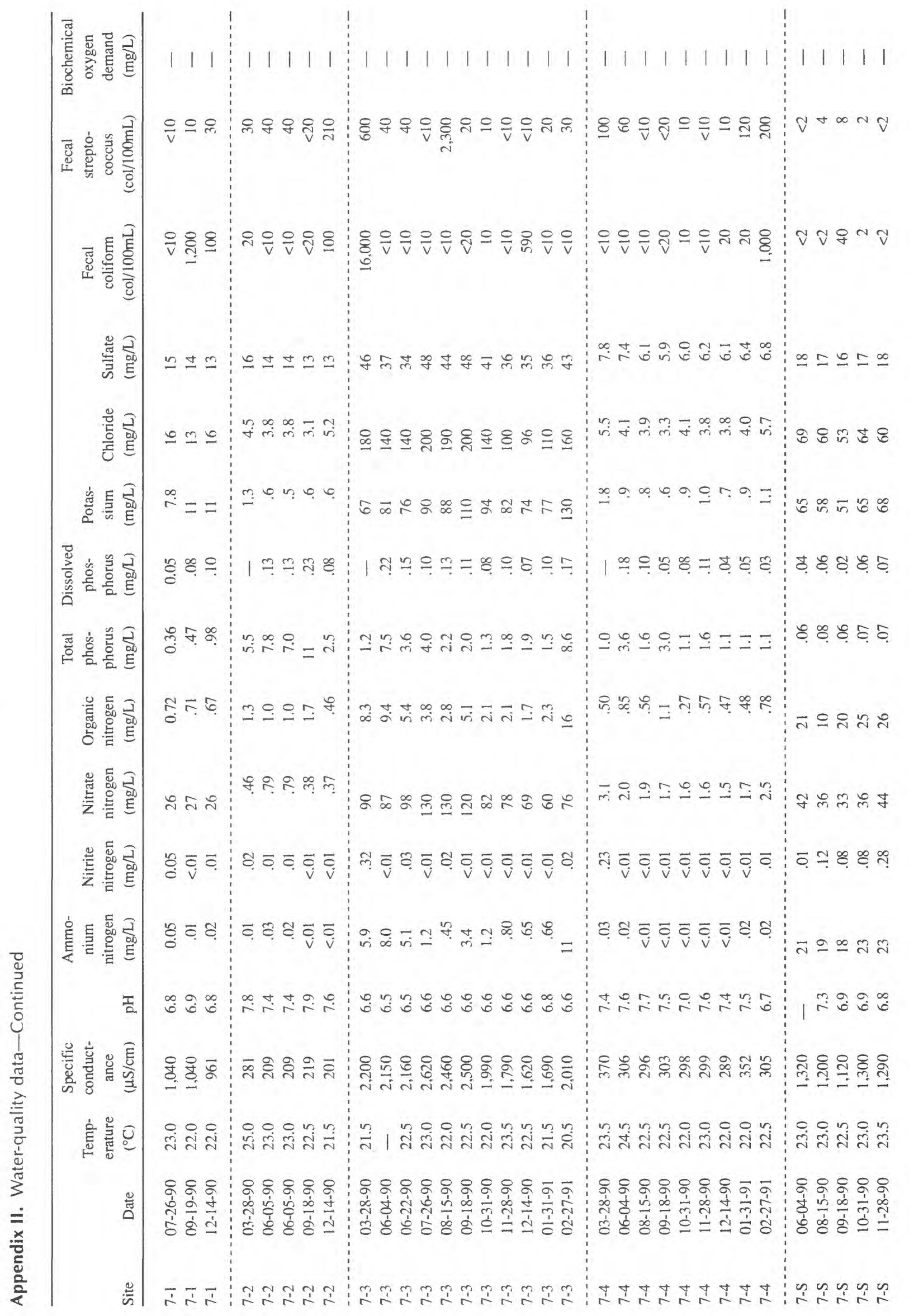




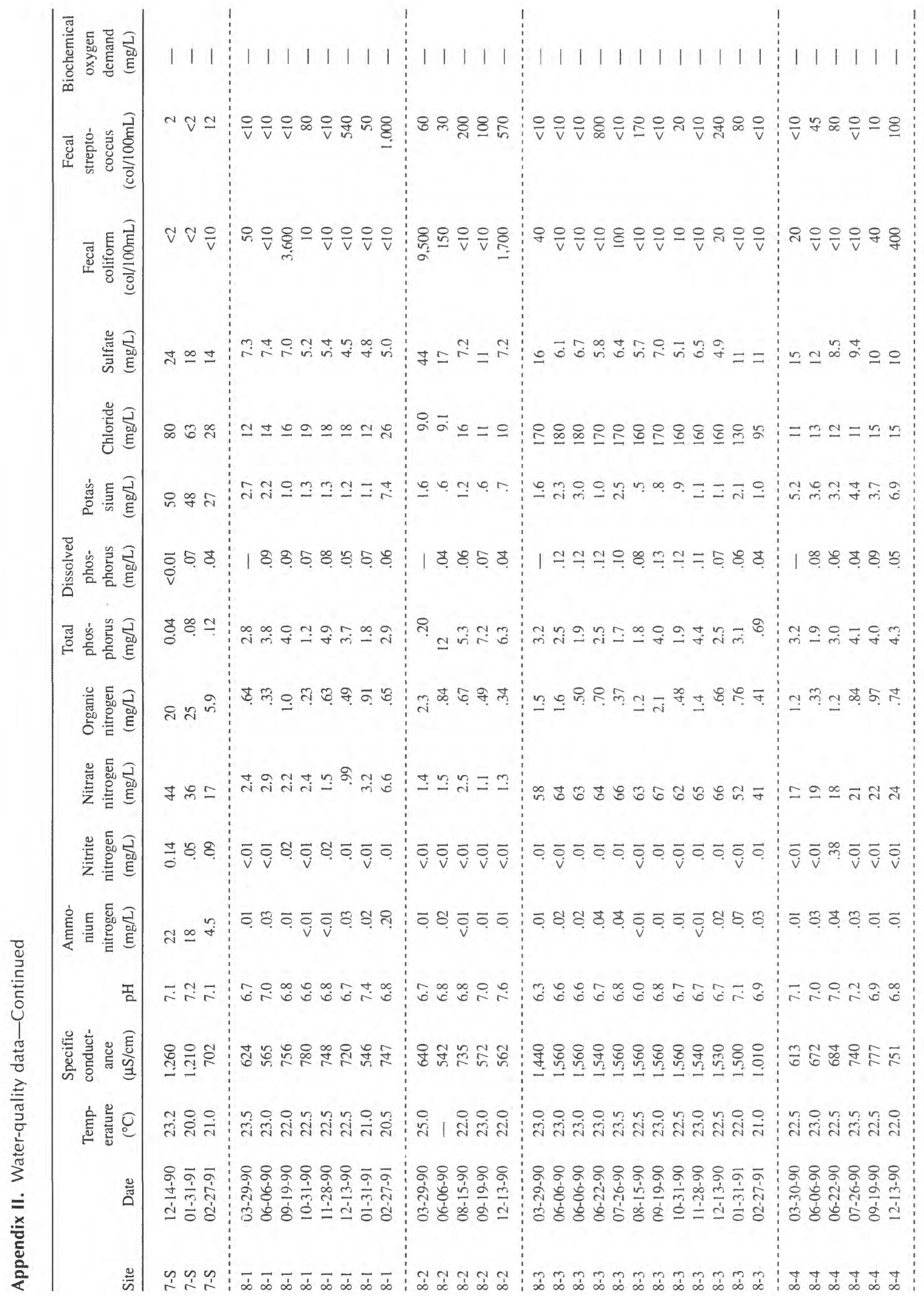




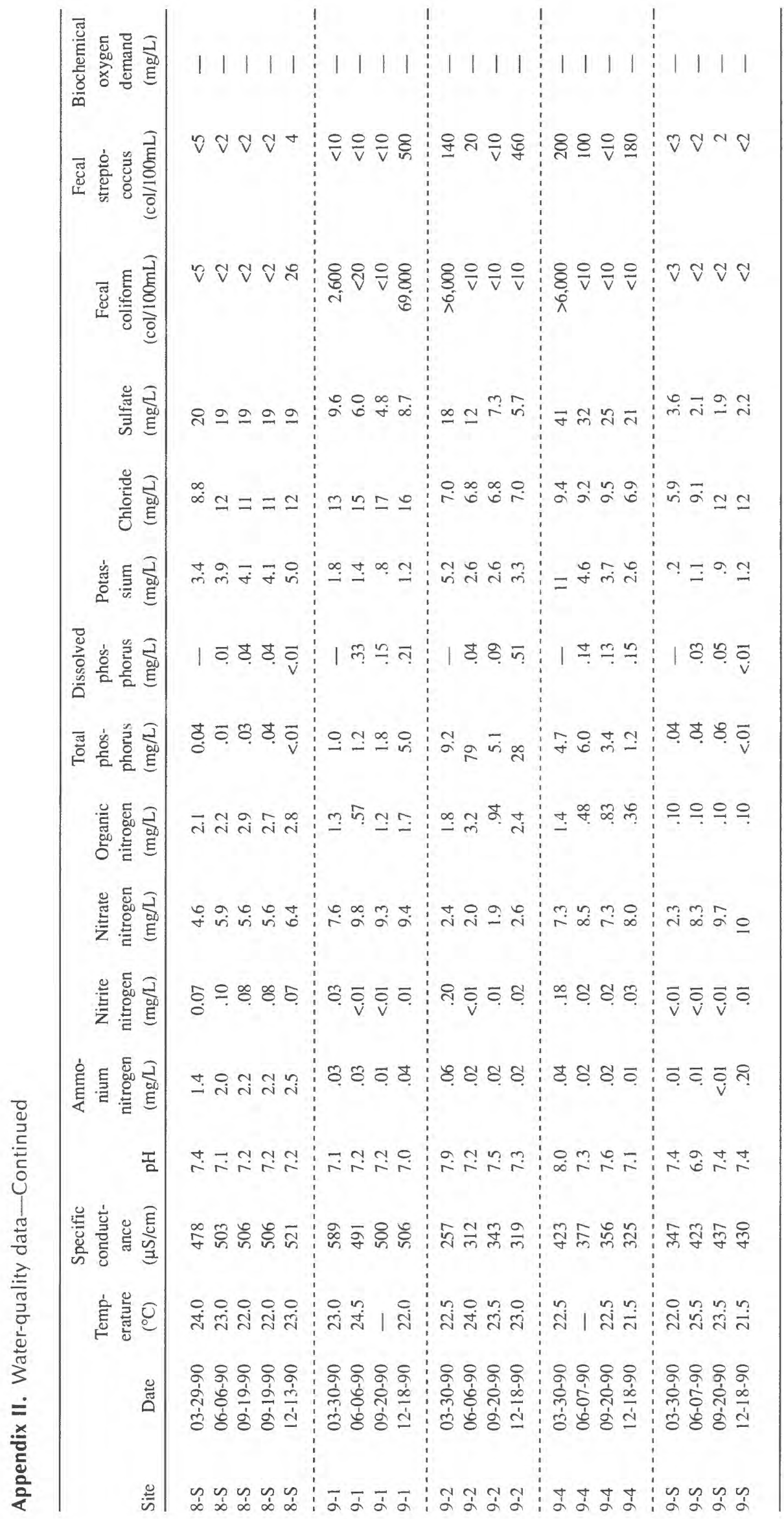

